\title{
Seasonal occurrence and abundance of caridean shrimp larvae at Helgoland, German Bight
}

\author{
Ingo S. Wehrtmann \\ Universität Hamburg, Zoologisches Museum und Zoologisches Institut (Abteilung Cru- \\ stacea); Martin-Luther-King-Platz 3, D-2000 Hamburg 13, Federal Republic of Germany
}

\begin{abstract}
Plankton samples were collected from January 1985 to January 1986 three times per week at Helgoland to study seasonal occurrence and abundance of caridean shrimp larvae. A total of eleven species were obtained. Ninety-one \% of all larvae collected during the sample period belonged to Crangon crangon L. and Crangon allmanni Kinahan, $6 \%$ to Philocheras trispinosus Hailstone and $3 \%$ to the remaining eight species. Collections were generally dominated by $C$. crangon larvae. However, $C$. allmanni larvae were most abundant in June coinciding with hatching activities of the population near Helgoland. $C$. allmanni was observed to have the highest density of all species with approximately 8 larvae per $\mathrm{m}^{3}$. Larvae of Eualus occultus (Lebour), Eualus pusiolus (Kroyer), Hippolyte varians Leach and Athanas nitescens Leach were most likely released by populations inhabiting the rocky intertidal zone around Helgoland. The presence of Processa modica Williamson \& Rochanaburanon and Processa nouveli holthuisi.Al-Adhub \& Williamson in the German Bight was verified by observations of a series of different developmental stages. Larvae of the rare species Caridion steveni Lebour were also recorded. The observed shrimp species were placed into three different groups with respect to their seasonal occurrence. Possible advantages of the timing of larval dispersal relative to predation and food availability are given. The results on seasonal occurrence and relative abundance are discussed in relation to environmental factors (temperature, salinity) as well as to the geographical distribution of the species.
\end{abstract}

\section{INTRODUCTION}

Larvae represent the "neglected link" (Costlow \& Bookhout, 1970) between generations of adult organisms. In order to investigate processes influencing and determining their population dynamics, it is not sufficient to focus only on the biology of the adults. The different developmental stages are important since they are responsible for the recruitment of populations, dispersal of species and the colonization of new environments. Among coastal and estuarine benthic species gene-flow can be limited by larval dispersal. However, pelagic invertebrate larvae can be transported over long distances by ocean currents, resulting in a genetic exchange between widely separated populations (Scheltema, 1975, 1986).

Although, more than 70 years ago, Wedemeyer (1912) provided information on the occurrence and distribution of shrimps in the North Sea, caridean shrimps inhabiting the German Bight have largely been ignored. However, there have been historical (Dalla- 
Torre, 1889; Schellenberg, 1928; Caspers, 1939) and recent studies (Janke, 1986) on shrimps that inhabit the Helgoland region which is the only rocky island in the Southern North Sea. Other studies concerning the biology of these decapods have been conducted along the Dutch coast (Holthuis, 1950; Adema et al., 1982). Several investigations have been carried out on the occurrence and distribution of decapod larvae in the North Sea (Rees, 1952, 1955; Baan et al., 1972; Sankarankutty, 1975; Lindley, 1987). It has been demonstrated that the plankton from the southern region of the North Sea in summer is characterized by large quantities of decapod larvae and fish larvae (Möller, 1980).

Most studies on caridean shrimps in the North Sea deal with the common shrimp, Crangon crangon, due to its commercial value for the coastal fisheries of this region. This is true for the adults (for recent reviews on landing and life cycle see, for example, Tiews, 1970, 1983; Henderson \& Holmes, 1987) as well as for their larvae. Descriptions of the different developmental stages mainly obtained from plankton samples (Kingsley, 1886; Ehrenbaum, 1890; Williamson, 1901) and more recently by laboratory-reared larvae are available (Gurney, 1982; Criales, 1985).

Studies on the seasonal occurrence and distribution of $C$. crangon larvae in the German Bight and adjacent estuaries were carried out by Kühl \& Mann (1963a, 1963b, $1963 c, 1968,1969,1971)$, Plett (1965) and Elss (1973). However, information of shrimp larvae other than $C$. crangon for this part of the North Sea is still unavailable. This study focuses on the species composition at Helgoland in order to confirm or extend the known geographical distribution of different species. The results may serve as a basis for further investigations documenting changes in species composition and relative abundance. Based on a one-year sampling period, this paper is the first of its kind to report on the seasonal occurrence and relative abundance of different shrimp larvae at Helgoland.

\section{MATERIAL AND METHODS}

\section{Sample collections and handling of material}

Depending on the weather conditions, sampling was generally conducted three times a week near Helgoland ("Helgoland-Reede") from January 1985 to January 1986, normally in the morning between 7 and $10 \mathrm{a} . \mathrm{m}$. at one of the three stations shown in Figure 1. A CALCOFI-net ("California Cooperative Oceanic Fisheries Investigations") with a mesh size of $500 \mu \mathrm{m}$ was used. Oblique tows were taken at stations with an average depth of 10 meters. The net was equipped with a flow meter. An average water volume of approximately $75 \mathrm{~m}^{3}$ per sample was filtered. However, due to the fluctuating numbers of shrimp larvae during the different seasons, the filtered volume per collections ranged from approximately $32 \mathrm{~m}^{3}$ to $136 \mathrm{~m}^{3}$. Temperature and salinity were measured at the surface. Plankton samples were concentrated and preserved in a buffered solution of $4 \%$ formaldehyde in sea water.

In the laboratory, all shrimp larvae from the entire sample were sorted and counted under a dissecting microscope. The determination of the larval stages was carried out with a light microscope. 


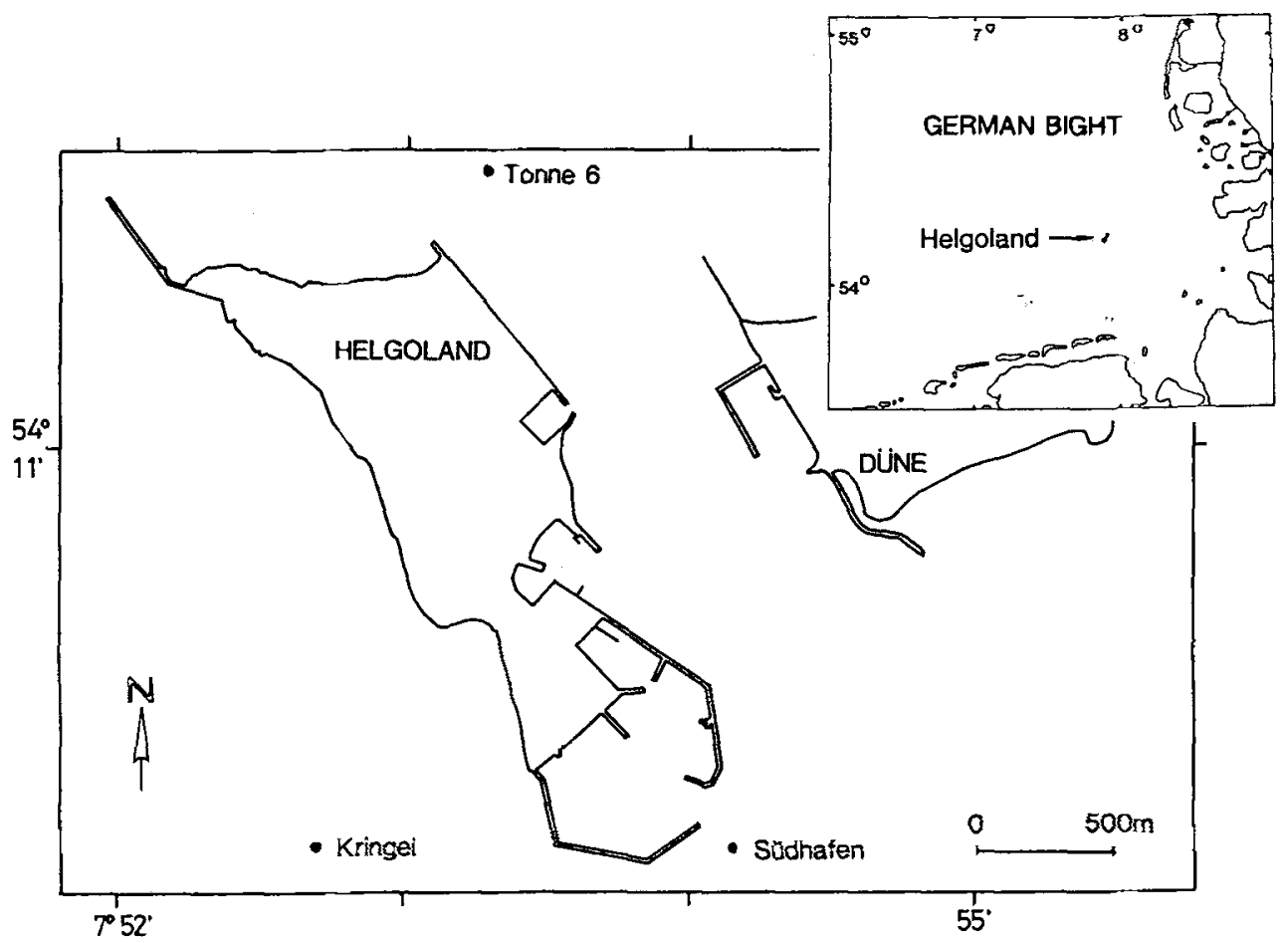

Fig. 1. Location of the sample stations at Helgoland

Identification of shrimp larvae and their developmental stages

Identification to the family level was performed using the key provided by Williamson (1957a). When available, larval descriptions of species and their developmental stages were consulted: Crangon crangon (Williamson, 1960; Gurney, 1982; Criales, 1985), Crangon allmanni (Williamson, 1960; Criales, 1985), Philocheras bispinosus (Williamson, 1960; Pike \& Williamson, 1961a), Philocheras trispinosus (Williamson, 1960; Pike \& Williamson, 1961a), Eualus pusiolus and Eualus occultus (Williamson, 1957b; Pike \& Williamson, 1961b), Processa modica and Processa nouveli holthuisi (Williamson \& Rochanaburanon, 1979), Hippolyte varians (Sars, 1912; Lebour, 1931; Williamson, 1957b), Athanas nitescens (Sars, 1906; Webb, 1921; Lebour, 1932; Williamson, 1957b) and Caridion steveni (Lebour, 1930; Williamson, 1957b).

For C. crangon and C. allmanni, no separation of different forms in each larval stage, as described by Criales (1985), was conducted. Pike \& Williamson (1961a) differentiated between $P$. b. bispinosus and $P$, bispinosus neglectus, All larvae of this species identified in the present study belonged to $P, b$. bispinosus. No detailed larval descriptions ionly for stage I and V) were available for $P$. trispinosus. Therefore, larval stages were distinguished by the development of the telson as described for $P$, bispinosus (Pike \& Williamson, 1961a). Identification of the first two stages of A. nitescens larvae was performed following descriptions by Webb (1921). All the other stages were identified using characteristics provided by Sars (1906) and Lebour (1932). 


\section{RESULTS AND DISCUSSION}

\section{Hydrography}

The monthly average temperatures at Helgoland-Reede (Fig. 2) from January to April 1985 were extraordinarily cold compared with long-term mean temperatures from the same area (Reichard, 1910; Goedecke, 1952, 1954; Weigel, 1976). The spring rise in temperature started in May. Values increased through August, peaking at $16.4^{\circ} \mathrm{C}$, and then decreased through January 1986. October and November were characterized by a rapid decline in temperature.

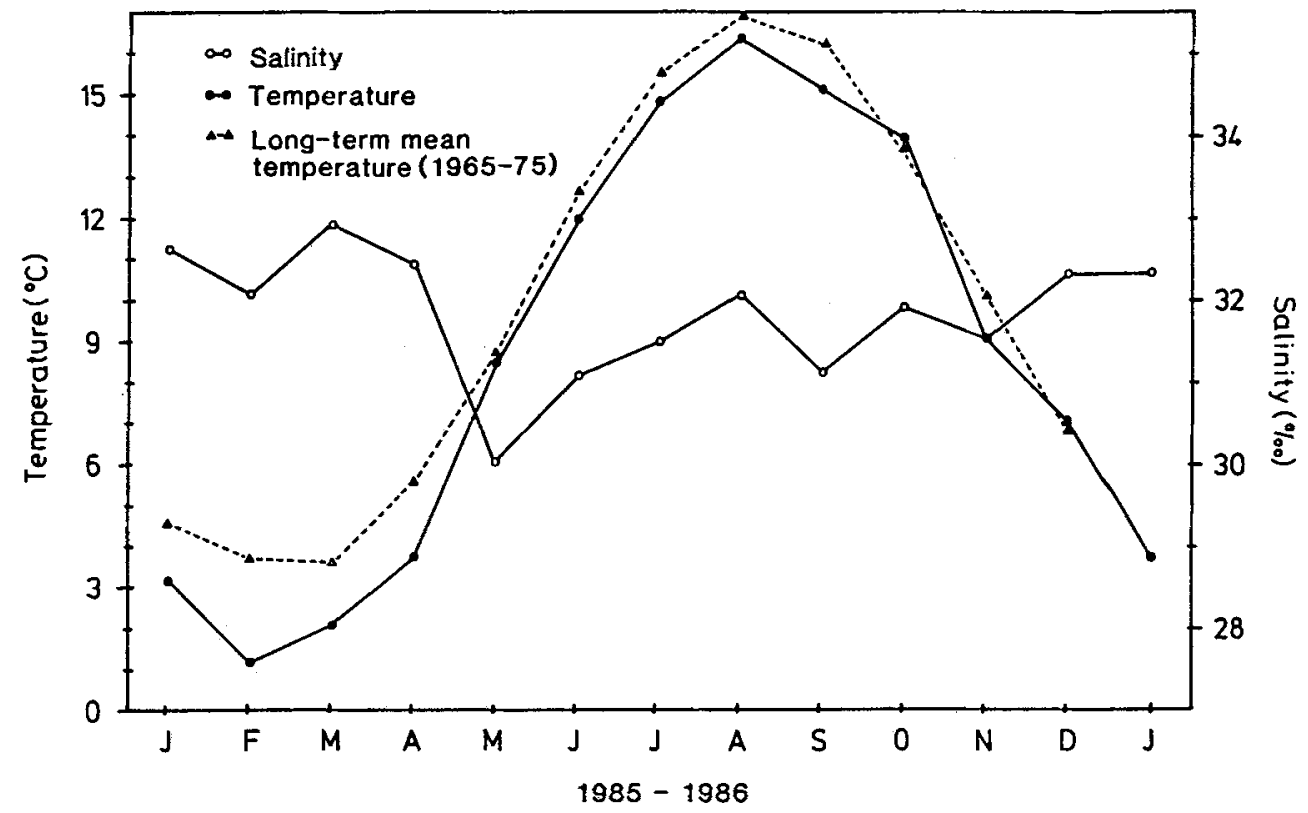

Fig. 2. Mean monthly temperatures and salinities during the sample period at Helgoland compared with long-term average temperatures, 1965-1975 (Weigel, 1976), from the same location

The average monthly salinities did not exhibit a very clear pattern (Fig. 2). However, during winter the mean value was generally higher than in summer. The lowest mean value was in May $(30.11 \%)$, probably indicating a fresh water input originating from the adjacent rivers Elbe and Weser. In August, the salinity was fairly constant at $32.25 \%$, while during most other months daily changes were observed.

\section{Seasonal abundance of the collected species}

\section{Crangon crangon (Linnaeus, 1758)}

Seasonal occurrence started in early May 1985 (Fig. 3). Larvae were found throughout the remainder of the entire sampling period, although very few were collected in the 


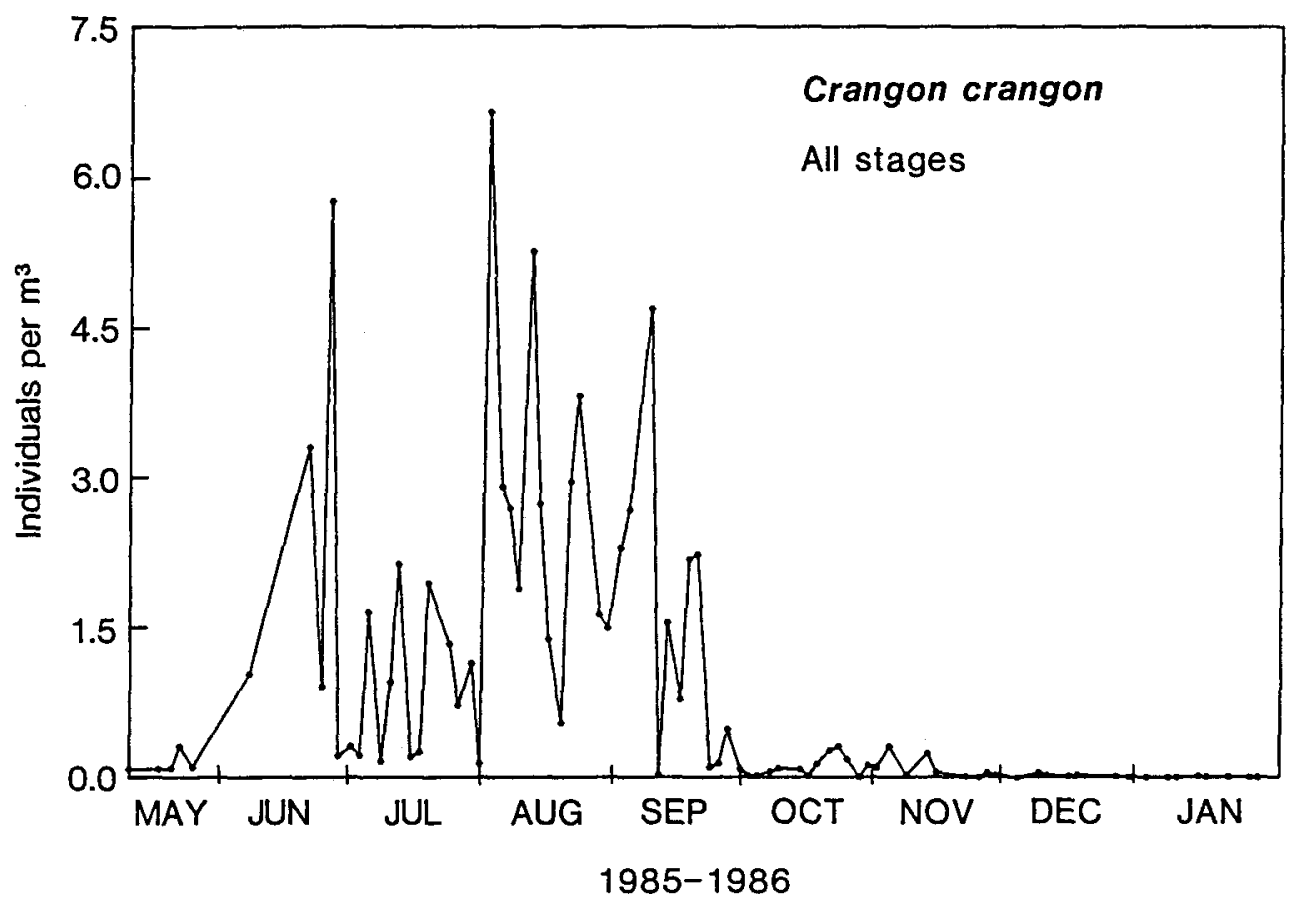

Fig. 3. Concentration of Crangon crangon larvae and juveniles during the study period at Helgoland

last two months (December 1985 and January 1986). Larvae were very common from June to September 1985 with peak abundance (approx. 7 larvae per $\mathrm{m}^{3}$ ) in August. The plankton samples contained all larval stages as well as juveniles. However, the most abundant larvae were in stage VII (Fig. 4) comprising $31 \%$ of the total number of $C$. crangon larvae. Stage I larvae had a distinct peak in June, while all other larval stages and juveniles reached their maximum in August (Fig. 5). Stage I larvae appeared for the first time in the plankton in the second week of May 1985 when water temperature reached $7.8^{\circ} \mathrm{C}$, and increased in numbers in May and June with increasing temperature. Between August 2 and 23 no stage I larvae were found, but they occurred regularly until October 1985. The last stage I larvae were taken in early December at a temperature of $6.4^{\circ} \mathrm{C}$.

The results of the present study concerning seasonal abundance of $C$. crangon larvae are generally in agreement with the findings of previous investigations (Table 1). Kühl (1972) reported Crangon larvae occurring in the Elbe estuary from February to December. The late beginning of $C$. crangon occurrence at Helgoland in 1985 may be explained by the extremely cold winter in 1984/1985 reported for the German coast of the North Sea (Koslowski, 1985) and by the resulting low temperatures in the first part of the year. After the exceptionally severe winter in 1962/1963, C. crangon larvae were not found in April 1963 probably due to low temperature of $4^{\circ} \mathrm{C}$ (Plett, 1965). However, plankton samples taken in April 1964 at temperatures between $4.0^{\circ} \mathrm{C}$ and $5.5^{\circ} \mathrm{C}$ contained shrimp larvae. Elss (1973) reported C. crangon larvae from April 1967 collected at 


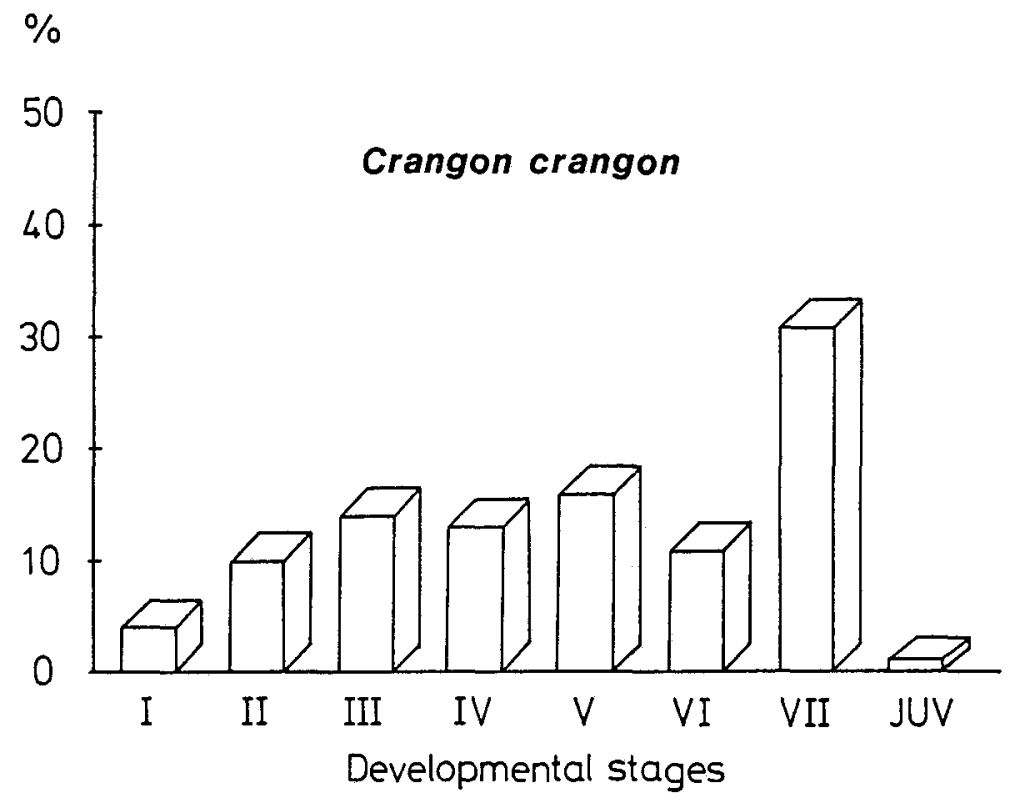

Fig.4. Crangon crangon. Percentage of larval stages and juveniles collected during the sample period at Helgoland $(n=5247)$

temperatures between $6.6^{\circ} \mathrm{C}$ and $7.0^{\circ} \mathrm{C}$. After a mild winter in 1982 , Gerdes (1985) obtained the larvae as early as March 1983 at an average temperature of $4.5^{\circ} \mathrm{C}$.

Previous investigations on $C$. crangon larvae in the German Bight confirm the results of the present study concerning maximum concentration during the seasonal occurrence: both Elss (1973) and Plett (1965) reported highest density of the larvae in August, while Kühl \& Mann (1963a) obtained peak abundance in the Elbe estuary in June. In the North Sea, plankton samples collected in September contained the highest number of $C$. crangon larvae (Lindley, 1987). Contrary to the present study, Rees (1952) observed a maximum of larval abundance in January. However, those data may not be representative, as they are based upon only 150 larvae collected within three years. Maximum numbers of $C$. crangon larvae collected in 1985-86 were relatively high compared with other results from the Southern North Sea; Lindley (pers. comm.) found a maximum concentration of 1 larva per $\mathrm{m}^{3}$ in April 1981 and September 1983.

The difference in time between the first peak of abundance of stage I and II was 7 days (Fig.6), which represents the duration of development of stage I. The mean temperature in this period was $11.0^{\circ} \mathrm{C}$. These field data are in good agreement with laboratory studies on larval stage development in C. crangon by Criales \& Anger (1986). They expressed the number of larval moults $(\mathrm{M})$ as a function of both temperature $\left(\mathrm{T}_{;}{ }^{\circ} \mathrm{C}\right)$ and time of development ( $D_{i}$ days):

$$
\mathrm{M}=0.00584 \cdot \mathrm{D} \cdot \mathrm{T}^{1.347}
$$

Based on the 1985 field data $\left(T=11.0^{\circ} \mathrm{C} ; \mathrm{M}=1\right)$, the estimated larval development (D) using this equation was also approximately 7 days. 


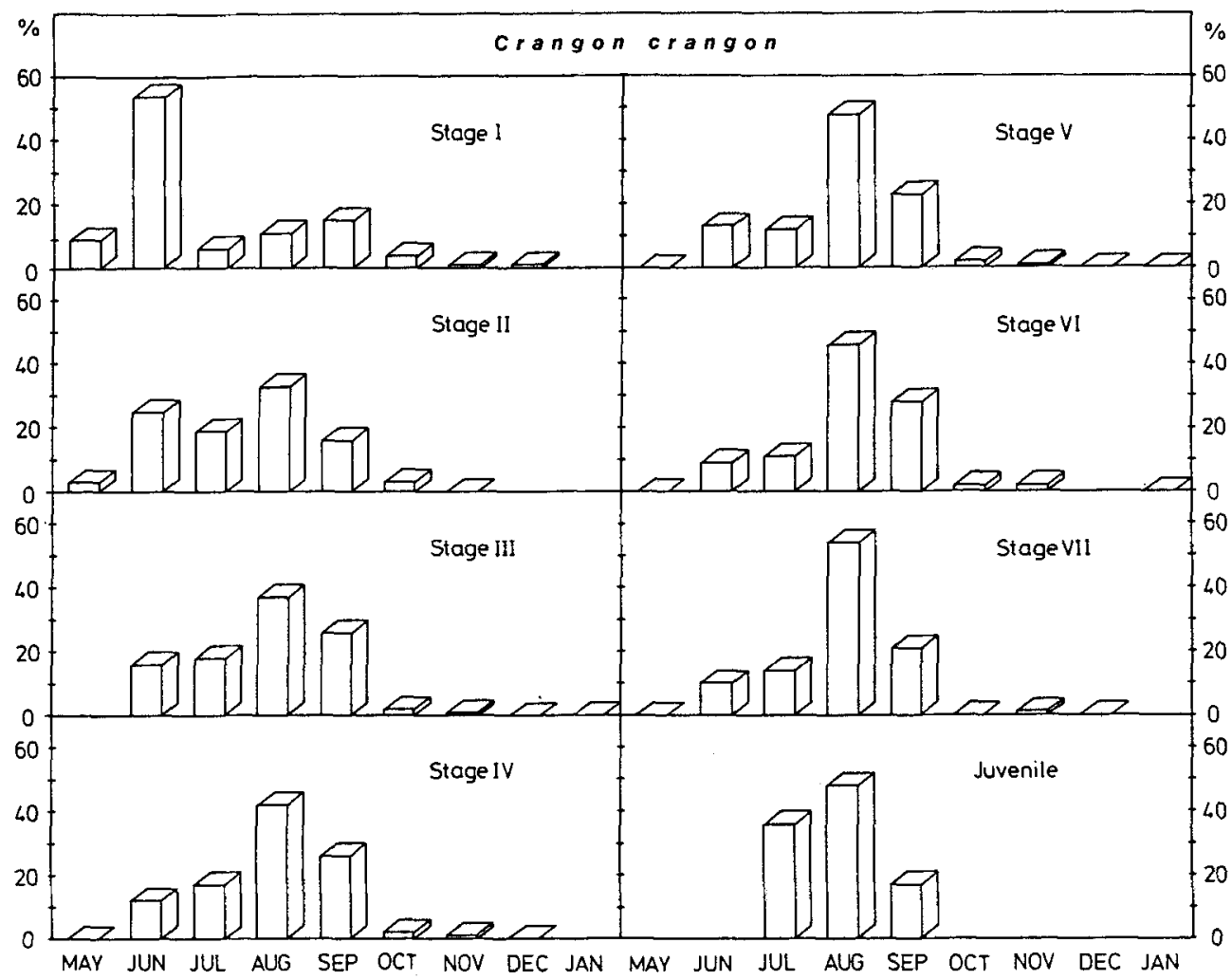

Fig.5. Crangon crangon. Seasonal occurrence of larval stages, and juveniles during the sample period at Helgoland $(n=5247)$. The values of all bars for each developmental stage add up to $100 \%$, representing the total number of collected larvae and juveniles per stage during the study period

Table 1. Seasonal occurrence of $C$. crangon larvae in the North Sea based upon the findings of different authors

\begin{tabular}{|c|c|c|c|c|c|c|c|c|c|c|c|c|c|}
\hline Author (year) & Location & Jan & Feb & Mar & Apr & May & Jun & Jul & Aug & Sep & Oct & Nov & $\checkmark$ Dec \\
\hline Lebour (1947) & British coast & $\mathrm{x}$ & $\mathrm{x}$ & $\mathrm{x}$ & $\mathrm{x}$ & $\mathrm{x}$ & $\mathrm{x}$ & $\mathrm{x}$ & $\mathrm{x}$ & $\mathrm{x}$ & $\mathrm{x}$ & $\mathrm{x}$ & - \\
\hline Rees (1952) & North Sea & $\mathrm{x}$ & $\mathrm{x}$ & $\mathrm{x}$ & $\mathrm{X}$ & $\mathrm{x}$ & $\mathrm{x}$ & $\mathrm{x}$ & $\mathrm{x}$ & - & - & - & $\mathrm{x}$ \\
\hline Jorgensen (1923) & British coast & - & - & - & - & $\mathrm{x}$ & $\mathrm{X}$ & $\mathrm{x}$ & $\mathrm{x}$ & $\mathrm{x}$ & - & - & - \\
\hline Thorson (1946) & Danish coast & - & - & - & - & $\mathrm{x}$ & $\mathrm{x}$ & $\mathrm{x}$ & $\mathrm{x}$ & $\mathrm{X}$ & $\mathrm{x}$ & - & - \\
\hline Kühl \& Mann (1963a) & Elbe estuary & - & - & $\mathrm{x}$ & $\mathrm{X}$ & $\mathrm{x}$ & $\mathrm{x}$ & $\mathrm{x}$ & $\mathrm{x}$ & $\mathrm{x}$ & $\mathrm{x}$ & $\mathrm{x}$ & $\mathrm{x}$ \\
\hline Künne (1952) & German Bight & $\mathrm{x}$ & - & $\mathrm{x}$ & $\mathrm{X}$ & $\mathrm{X}$ & $\mathrm{x}$ & $\mathrm{x}$ & $\mathrm{X}$ & $\mathrm{X}$ & $\mathrm{x}$ & $\mathrm{x}$ & $\mathrm{X}$ \\
\hline Lindley (1987) & North Sea & - & - & - & $\mathrm{x}$ & $\mathrm{x}$ & $\mathrm{X}$ & $\mathrm{x}$ & $\mathrm{x}$ & $\mathrm{x}$ & $\mathrm{x}$ & $\mathrm{x}$ & - \\
\hline Present study & Helgoland & $\mathrm{x}$ & - & - & - & $\mathrm{x}$ & $\mathrm{X}$ & $\mathrm{x}$ & $\mathrm{x}$ & $\mathrm{x}$ & $\mathrm{x}$ & $\mathrm{x}$ & $\mathrm{x}$ \\
\hline
\end{tabular}




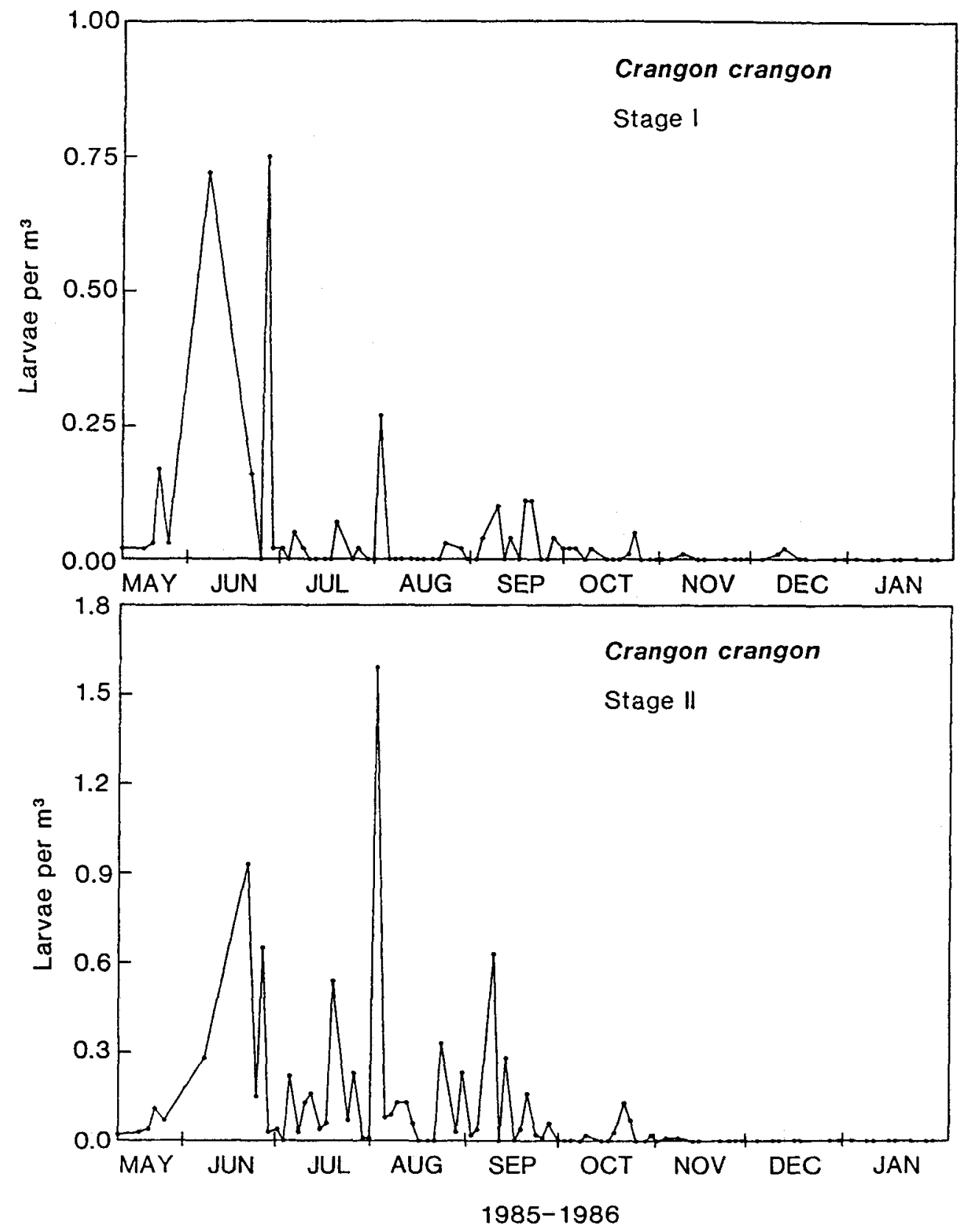

Fig. 6. Crangon crangon. Concentration of stage I and II larvae at Helgoland 
The findings of the present study on larval abundance of stage I (Fig. 6) suggest that there have been at least two main hatching periods in 1985 at Helgoland. The first period extending from early May to early August and the second from late August until October. The absence of newly hatched larvae during the first three weeks in August supports the separation of these hatching periods.

Crangon crangon populations around England spawn normally twice per annum (Meredith, 1952; Henderson \& Holmes, 1987). For the German Bight, Tiews (1954) reported three spawning periods at Büsum and observed very few egg-carrying females during September and October. However, the data of the present study do not allow a decision concerning the number of broods at Helgoland. Furthermore, the offshore sample station is not a favourable area for the common shrimp. According to Tiews (1970), C. crangon prefers Wadden Sea areas, especially highly productive estuaries with strong tidal movements of brackish water masses.

Crangon allmanni Kinahan, 1857

Larvae of C. allmanni were found in the plankton samples at Helgoland from May to September 1985 with a distinct peak in June (Fig. 7). In this month, 63\% of the total number of larvae occurred, while only $1 \%$ was obtained in May and September and $25 \%$ and $10 \%$ in July and August, respectively. Maximum concentration was observed in the second half of June with approximately 8 larvae per $\mathrm{m}^{3}$.

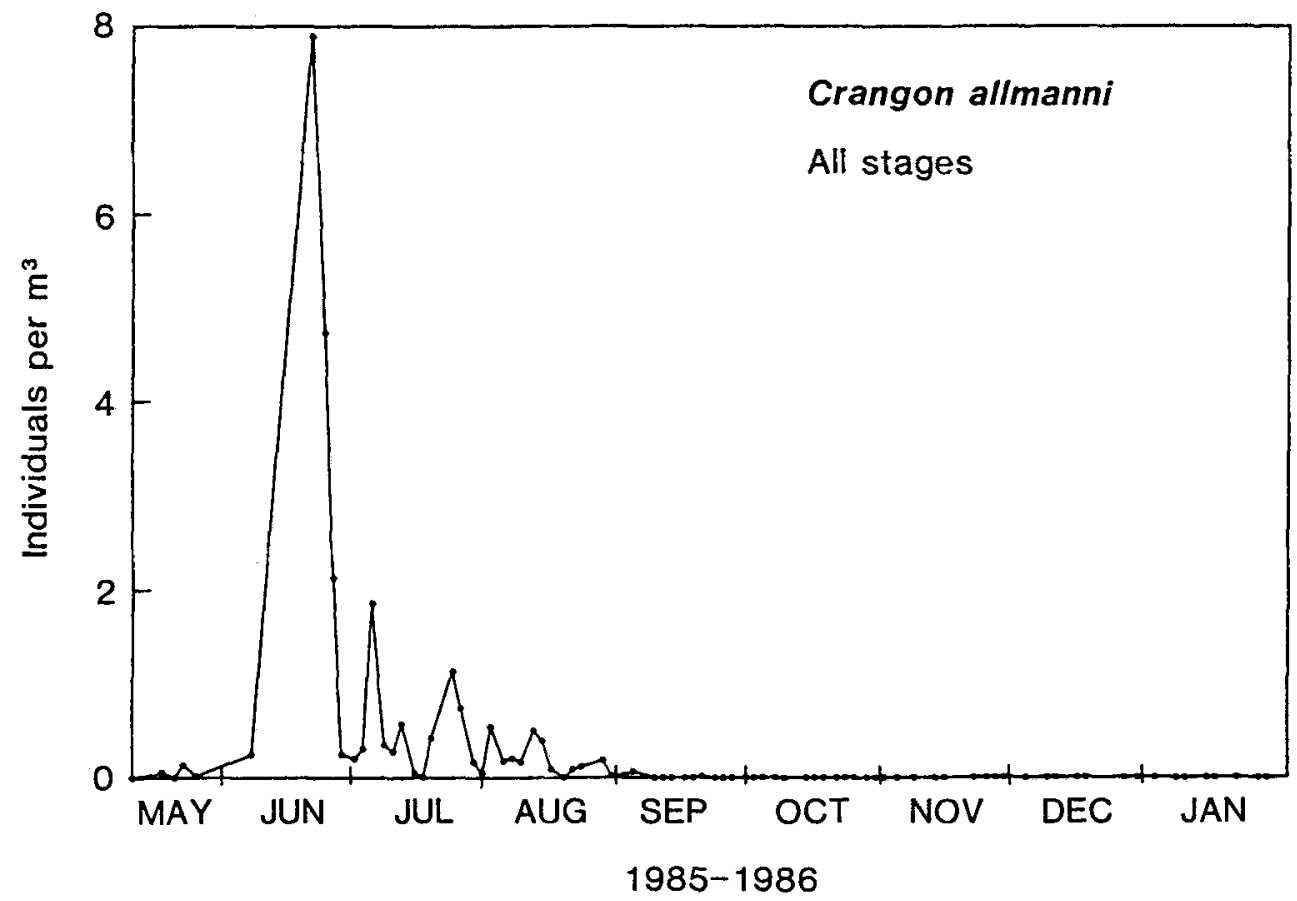

Fig.7. Crangon allmanni. Concentration of larvae and juveniles during the sample period at Helgoland 
All developmental stages including juveniles were collected. However, a predominance of the first three stages comprising approximately $82 \%$ of the total number was observed (Fig. 8). Stage I larvae were collected from mid-May to the end of August, reaching peak abundance at the end of June with approximately 6 larvae per $\mathrm{m}^{3}$. The range of temperature in which the stage I larvae were collected was $9.4^{\circ} \mathrm{C}$ to $16.3^{\circ} \mathrm{C}$. All larvae taken in May were either in stage I or II, while $54 \%$ of the C. allmanni larvae in July and August were stage III. Peak occurrence of stage IV was in June and July. Stage $V$ reached a distinct peak in August that represented more than $60 \%$ of the total larvae of that stage. The older developmental stages and juveniles occurred from late June to early September.

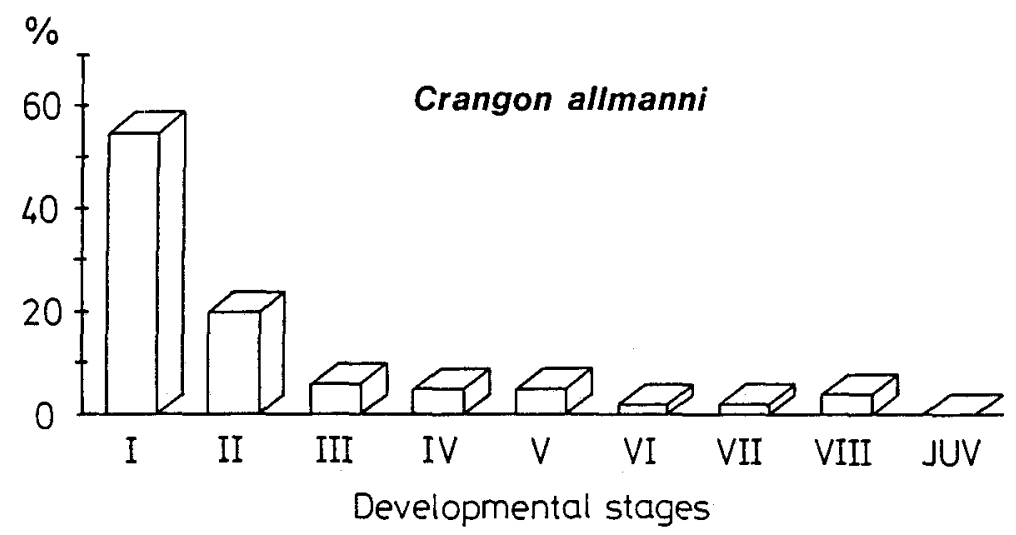

Fig. 8. Crangon allmanni. Percentage of larval stages and juveniles collected during the sample period at Helgoland $(\mathrm{n}=1682)$

Due to their similarity, larvae of $C$. crangon and $C$. allmanni have often not been separated (e.g. Baan et al. 1972; Weber, 1984); detailed information on the larval phase of C. allmanni is sparse. The results concerning seasonal occurrence of $C$. allmanni confirm generally the findings of previous studies (Rees, 1952; Allen, 1960; Lindley, 1987). Peak abundance of $C$. allmanni larvae in the North Sea occur in May/June (Allen, 1960; Lindley, 1987). In the Danish Wadden Sea area, Thorson (1946) reported the larvae between mid-April and late June.

It is noteworthy that in most of the studies on C. allmanni cited above, the period of larval occurrence extends through September. This may be explained by the pattern of reproduction; in both areas of the Dutch coast (Creutzberg \& Leeuwen, 1980) and off the Northumberland coast (Allen, 1960) C. allmanni has a breeding season from December to July. In autumn, no egg-bearing females were found. The maximum concentration of $C$. allmanni larvae $\left(8\right.$ specimens per $\mathrm{m}^{3}$ ) represents the highest density of all species obtained during the study period. Lindley (pers. comm.) obtained a considerably lower concentration of these larvae in the Southern North Sea with a maximum of 1.3 larvae per $\mathrm{m}^{3}$ in July 1983.

The complete larval development (until stage VIII) of C. allmanni requires approximately 46 days at a temperature of $12^{\circ} \mathrm{C}$ (Criales, 1985; Criales \& Anger, 1986). In the present study, the first stage I larvae occurred on May 15 and stage VIII larvae were first 
obtained on July 26 at an average temperature of $11.2^{\circ} \mathrm{C}$. The time difference between the occurrence of these two stages is 46 days, which represents exactly the findings from the rearing experiments, even though the water temperature at Helgoland varied from $8.1^{\circ} \mathrm{C}$ and $14.2^{\circ} \mathrm{C}$ during the six weeks.

C. allmanni larvae occur mainly around the English and Irish coasts and are uncommon in the eastern part of the North Sea (Lindley, 1987). The only known population of $C$. allmanni in the German Bight is located near Helgoland (Caspers, 1939). The predominance of the first larval stages (Fig. 8) indicates a hatching area of this species. The hatched larvae were probably transported away from the parent population by the current system. Because of the low abundance of larvae in advanced developmental stages, it seems unlikely that recruitment to the population near Helgoland is exclusively by larvae. There may also be an immigration of juveniles and adults from other parts of the North Sea. Observations from other Crangon populations concerning annual migrations (Allen, 1960, 1966; Boddeke, 1975, 1976) and restocking of parent populations by immigration of animals (Sandifer, 1975) support this hypothesis.

\section{Philocheras bispinosus (Hailstone, 1835)}

Larval occurrence of this species extended from July to December with a peak in August, September and October (Fig. 9). In December, the plankton samples contained very few larvae, while in January 1986 no $P$. bispinosus larvae were taken. The range of water temperatures in which these larvae were found was $7.3^{\circ} \mathrm{C}$ to $16.4^{\circ} \mathrm{C}$. Maximum

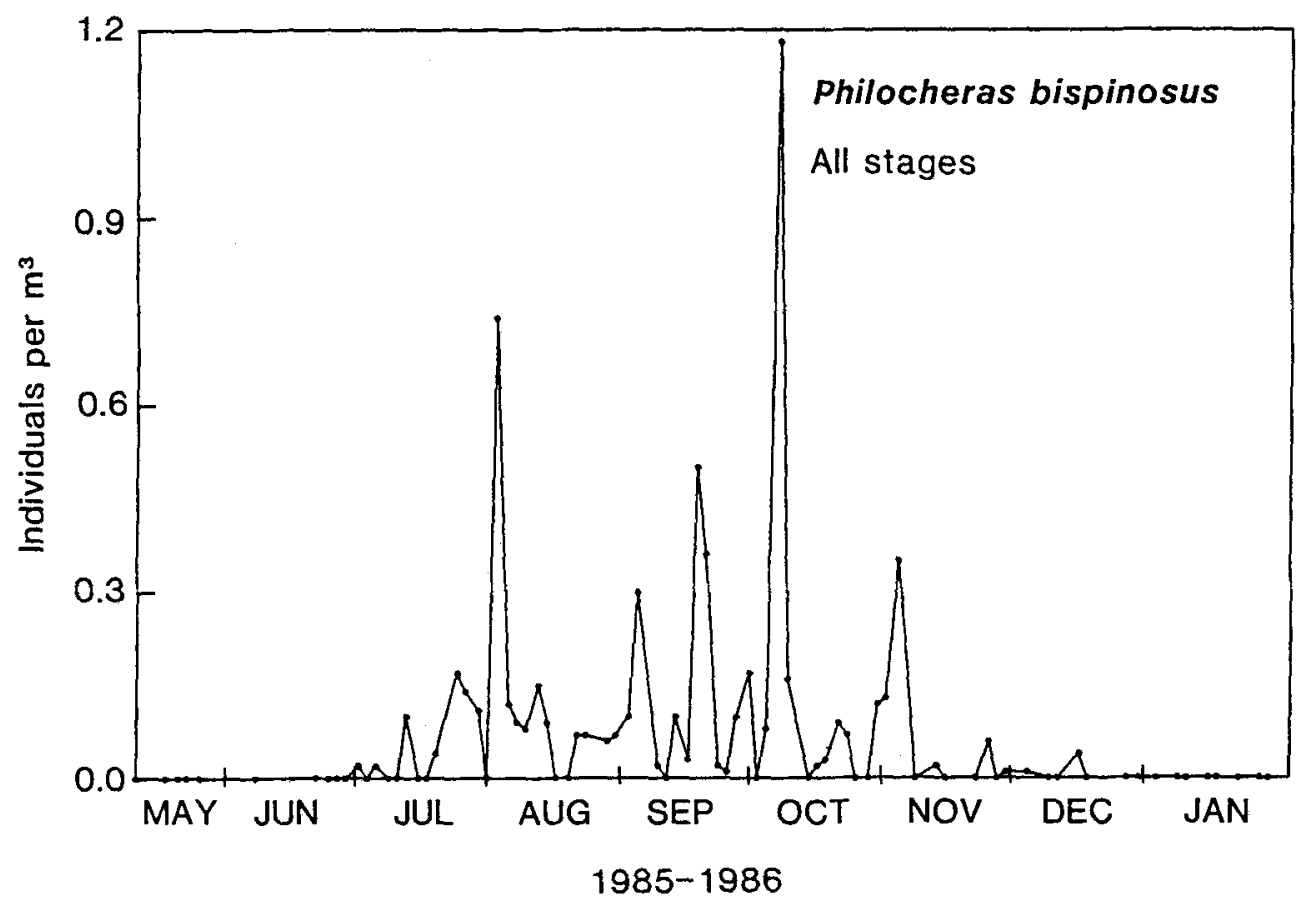

Fig. 9. Philocheras bispinosus. Concentration of the larvae and the juveniles during the sample period at Helgoland 
concentration was approximately 1 larvae per $\mathrm{m}^{3}$ in early October. Stage $\mathrm{V}$ was most abundant, comprising more than $40 \%$ of the collected $P$. bispinosus larvae (Fig. 10). In general, the number of collected larvae increased with developmental stage. However, only few juveniles were found between the end of October and mid-November. Larvae in stage I occurred from July to early November, and specimens in the last developmental stage were taken between the end of July and mid-December.

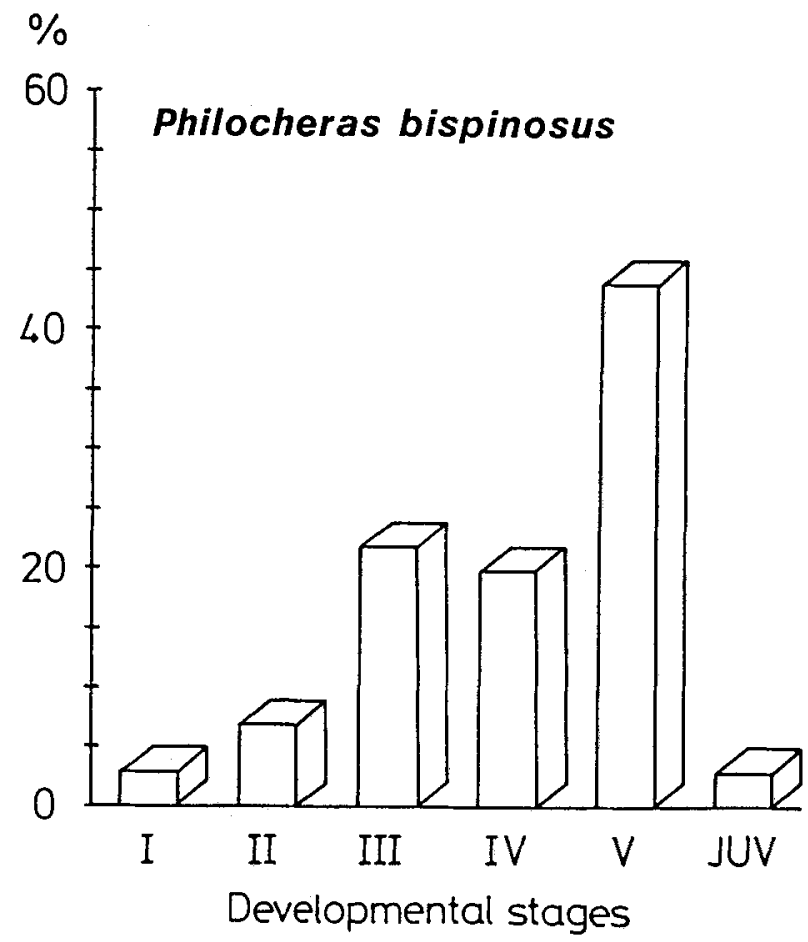

Fig. 10. Philocheras bispinosus. Percentage of larval stages and juveniles collected during the sample period at Helgoland $(n=479)$

Several other investigators have noted $P$. bispinosus larvae from the plankton larvae occurred rather late in the year, and peak abundance has been found between September and November (Thorson, 1946; Rees, 1952, 1955; Lindley, 1987). P. bispinosus larvae in the Adriatic Sea are present the whole year in low abundance, reaching the maximum in January (Kurian, 1965). At the south-western coast of Portugal, P. bispinosus larvae occur from October to March, in June, July and September (Paula, 1987). A predominance of older larval stages in the Danish Wadden Sea is documented by Thorson (1946).

Philocheras trispinosus (Hailstone, 1835)

Figure 11 shows that larvae were not numerous but were regularly taken between mid-July and early November. The peak in January 1986 represents one juvenile. Maximum concentration with approximately 0.1 larvae per $\mathrm{m}^{3}$ was in early October. $P$. trispinosus larvae reached peak abundance in August and again in October. The 


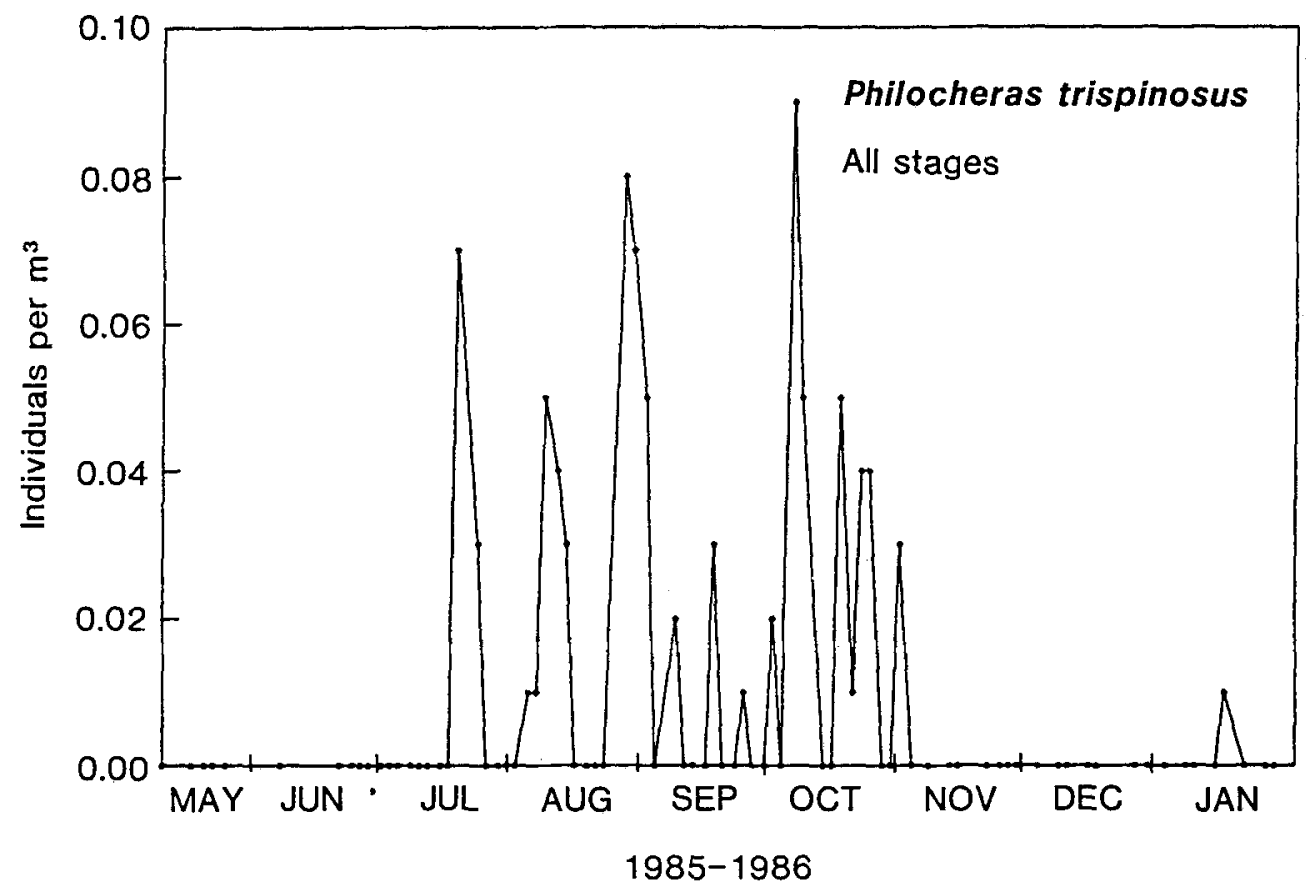

Fig. 11. Philocheras trispinosus. Concentration of larvae and juveniles during the sample period at Helgoland

larvae collected in August and October comprised more than $70 \%$ of the total number of $P$. trispinosus larvae. Only larvae in stages III, IV and V were found, with stage V being most abundant (Fig. 12).

Hitherto, no information on larval occurrence of $P$. trispinosus from the German Bight has been available. Baan et al. (1972) found Philocheras-larvae in the Southern North Sea near "Texel" lightship from July to January, but did not distinguish between $P$. bispinosus and $P$. trispinosus. However, the authors stated that the majority of the collected specimens belonged to the postlarval stage of $P$. trispinosus. Lindley (1987) observed the larvae of this species in the North Sea in July and August, and in the area of the English Channel from July to December. Maximum abundance in the English Channel occurred in August followed by the major peak in November. Information concerning seasonal occurrence of $P$. trispinosus larvae in the Mediterrarisan Sea and the coast of Portugal has been provided by Labat (1984) and Paula (1987), respectively.

\section{Eualus pusiolus (Kroyer, 1844)}

The few collected larvae of this species found within the sample period occurred from mid-June to July. Approximately 0.2 larvae per $\mathrm{m}^{3}$ represented the maximum concentration observed in mid-July (Fig. 13). Approximately $80 \%$ of the total number of the collected E. pusiolus larvae belonged to stages I and II. The larvae were captured over a temperature range of $11.5^{\circ} \mathrm{C}$ to $15.5^{\circ} \mathrm{C}$. The average temperature during the occurrence of $E$. pusiolus larvae was $13.8^{\circ} \mathrm{C}$. There have been no previous records from 


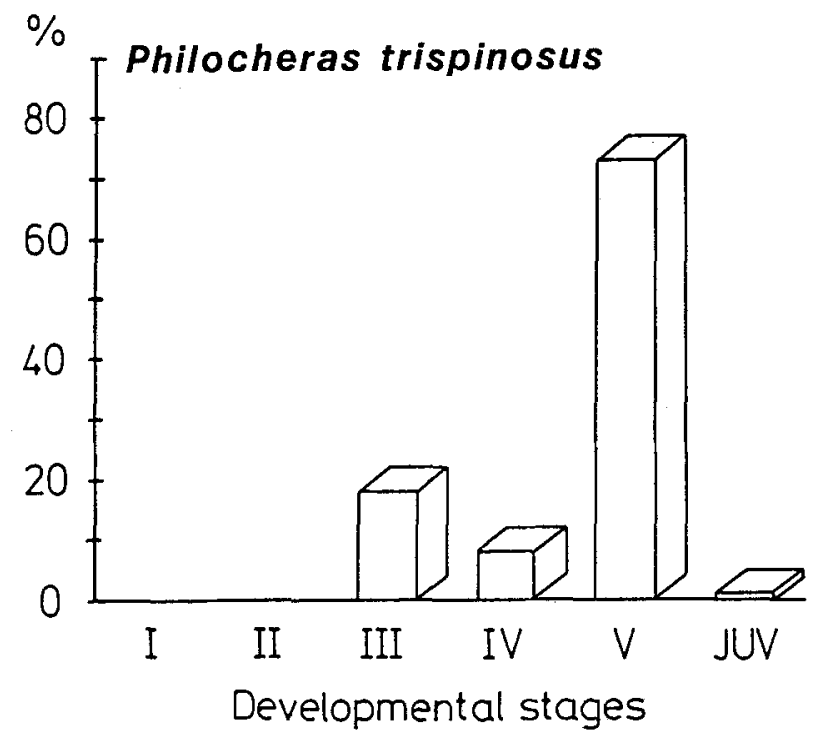

Fig. 12. Philocheras trispinosus. Percentage of larval stages and juveniles collected during the sample period at Helgoland $(n=53)$

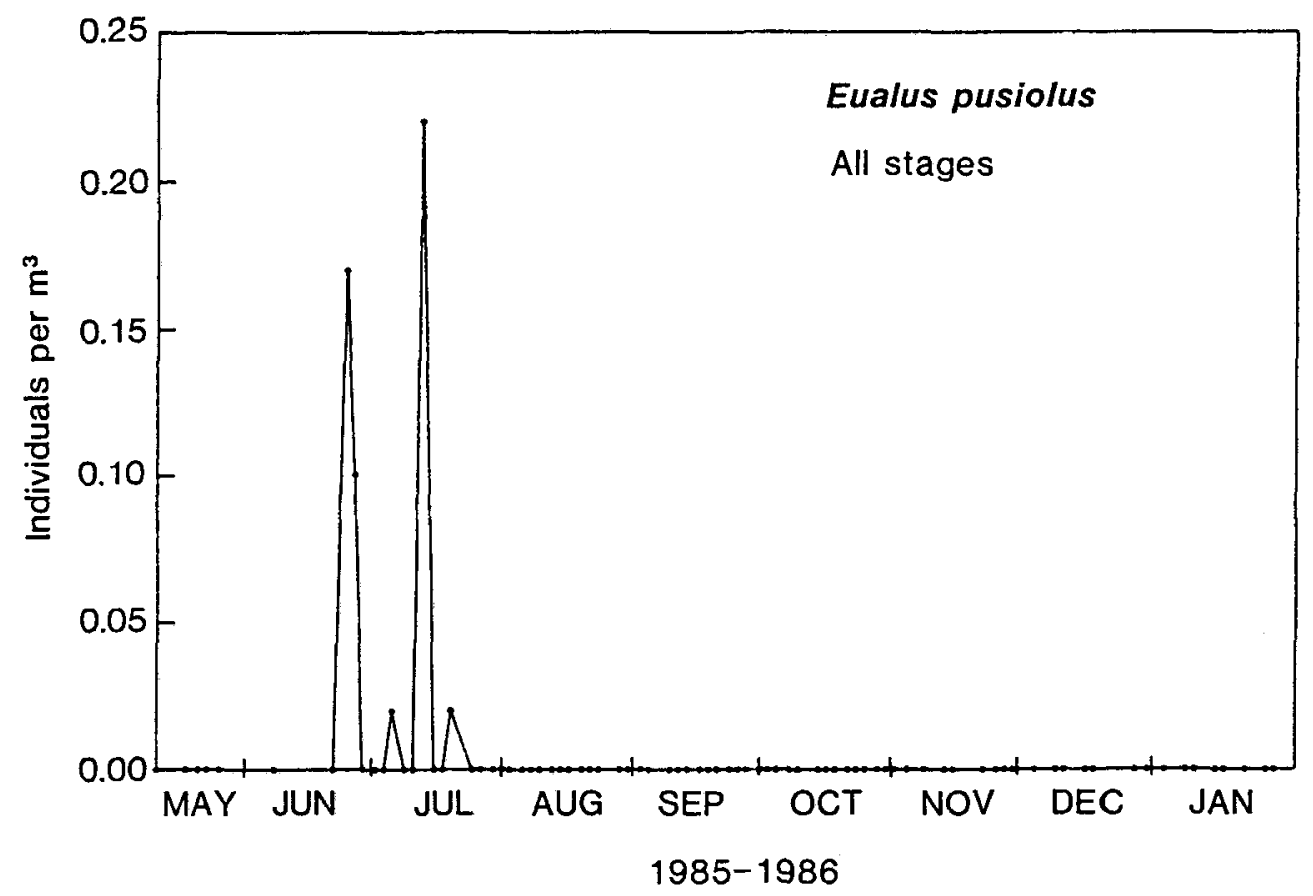

Fig. 13. Eualus pusiolus. Concentration of larvae during the sample period at Helgoland $(n=30)$ 
E. pusiolus at Helgoland. However, during the study period several adult specimens were collected near Helgoland. On March 6th 1986 an egg-bearing female was caught in Helgoland Harbour. These findings, as well as the predominance of the first two larval stages indicate that a population of $E$. pusiolus is located around Helgoland and that the study region represents a hatching area for this shrimp.

Larval occurrence extends in both the Irish Sea and the Firth of Clyde from February to August or September (Pike \& Williamson, 1961b). Lindley (1987) reported E. pusiolus larvae from the Irish Sea and the English Channel in February and May, respectively. These results may indicate an earlier hatching period of $E$. pusiolus larvae around the Atlantic coast of Great Britain and Ireland than at Helgoland, probably due to the generally higher temperature in early spring. June and July represent the beginning of the planktonic period of $E$. pusiolus larvae in the German Bight, indicated by the presence of newly hatched larvae. This may explain the difference in the length of seasonal occurrence compared with other studies (Bull, 1939; Pike \& Williamson, 1961b).

\section{Eualus occultus (Lebour, 1936)}

Figure 14 shows the seasonal occurrence of E. occultus larvae, starting in the second half of July and ending in early October. The majority of the larvae were collected in August $(58 \%)$ and September (39\%), while in July and October only $7 \%$ and $2 \%$ were taken, respectively. During the occurrence of $E$. occultus larvae the temperature varied from $14.5^{\circ} \mathrm{C}$ to $17.0^{\circ} \mathrm{C}$ with a mean temperature of $15.5^{\circ} \mathrm{C}$. Larval abundance was always

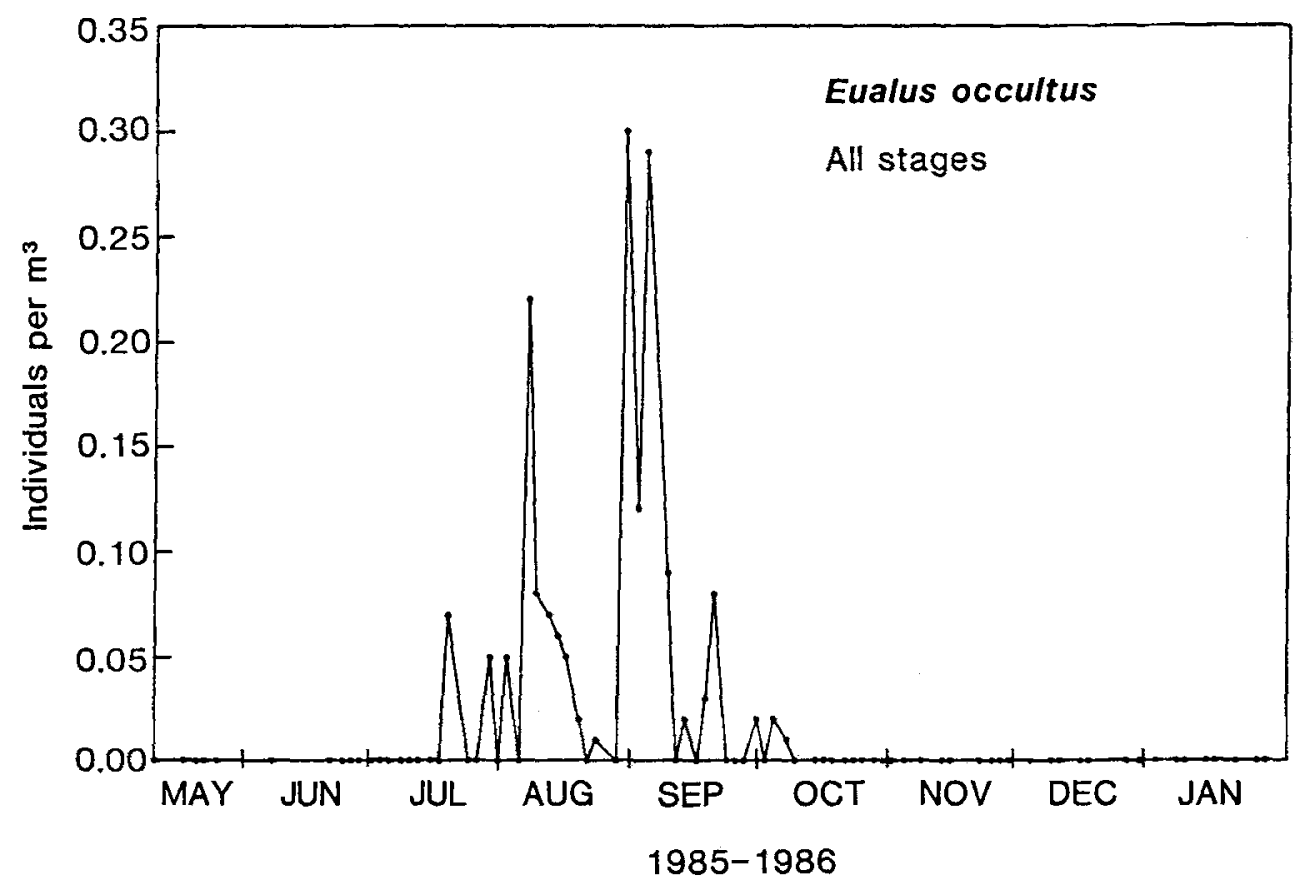

Fig. 14. Eualus occultus. Concentration of larvae and juveniles during the sample period at Helgoland 
low and reached maximum density in late August (ca 0.3 larvae per $\mathrm{m}^{3}$ ). Except stage $\mathrm{V}$, all developmental stages and juveniles occurred during the sample period at Helgoland (Fig. 15). The older stages were found earlier (from mid-June) than the younger ones, which were taken from August to October.

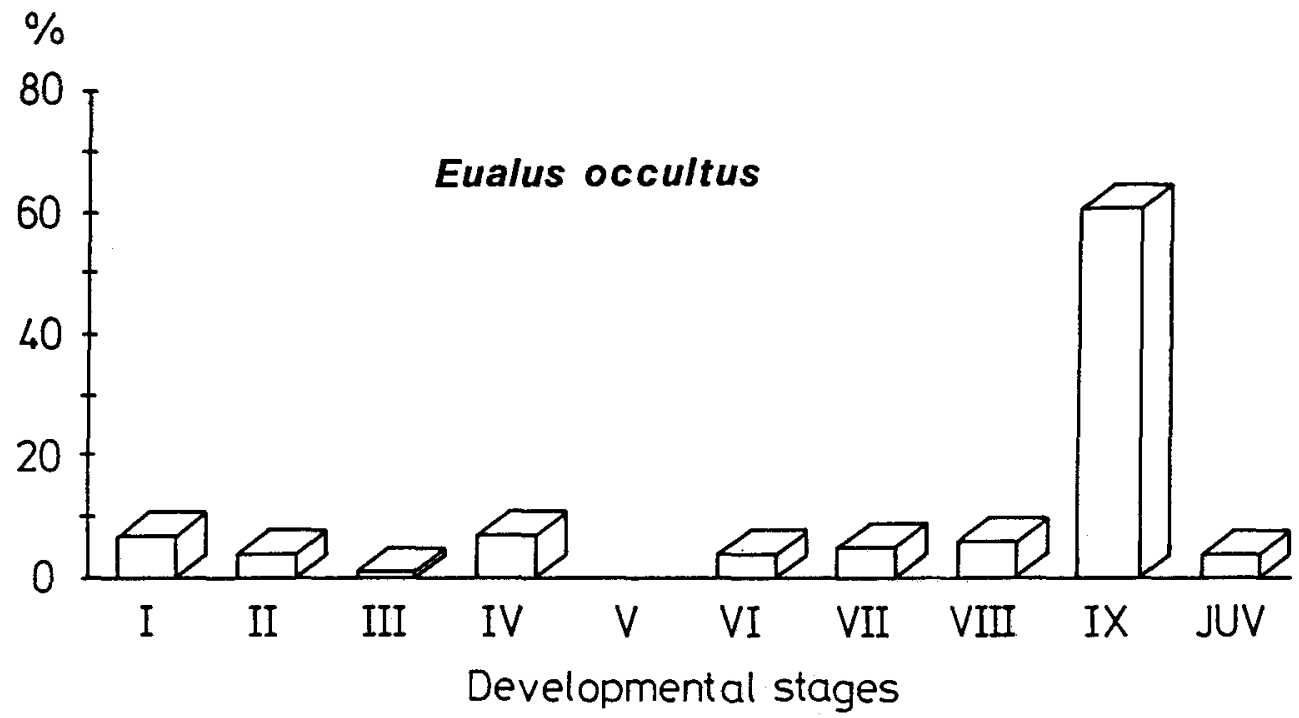

Fig. 15. Eualus occultus. Percentage of larval stages and juveniles collected during the sample period at Helgoland $(n=103)$

Due to their similarity, adult E. occultus and Thoralus cranchii (Leach) have often been confused. In contrast, larvae of these species can be easily distinguished by a pair of lateral spines on the 5th abdominal somite, which occurs only in $T$. cranchii larvae (Lebour, 1936; Pike \& Williamson, 1961b). Recently, Janke (1986) provided the first information of adult $E$. occultus from the rocky intertidal at Helgoland. This record can be supported by four adult specimens which were collected by other investigators during the sample period from test panels at Helgoland Harbour as well as by the presence of their larvae. The presence of older stages of $E$. occultus followed by the later occurrence of younger stages indicates an immigration of the advanced stages from other places, where the hatching period started earlier than in the German Bight. The parent population of these larvae may be located in the English Channel or the Irish Sea.

Processa modica Williamson \& Rochanaburanon, 1979

Larvae of this shrimp occurred from mid-June to early November (Fig. 16). They were never numerous with peak concentration observed on August 12 of approximately 0.1 larvae per $\mathrm{m}^{3}$. P. modica larvae were first caught when the temperature increased in 1985 to $15-16^{\circ} \mathrm{C}_{i}$ larvae reached peak abundance in August (58\%). More than $80 \%$ of all larvae occurred in August and September, with $12 \%$ in July and the remainder in October and November. All larval stages were found at Helgoland (Fig. 17). Larvae in stages I to IV were collected from July to September, and the older stages were obtained from August to November. 


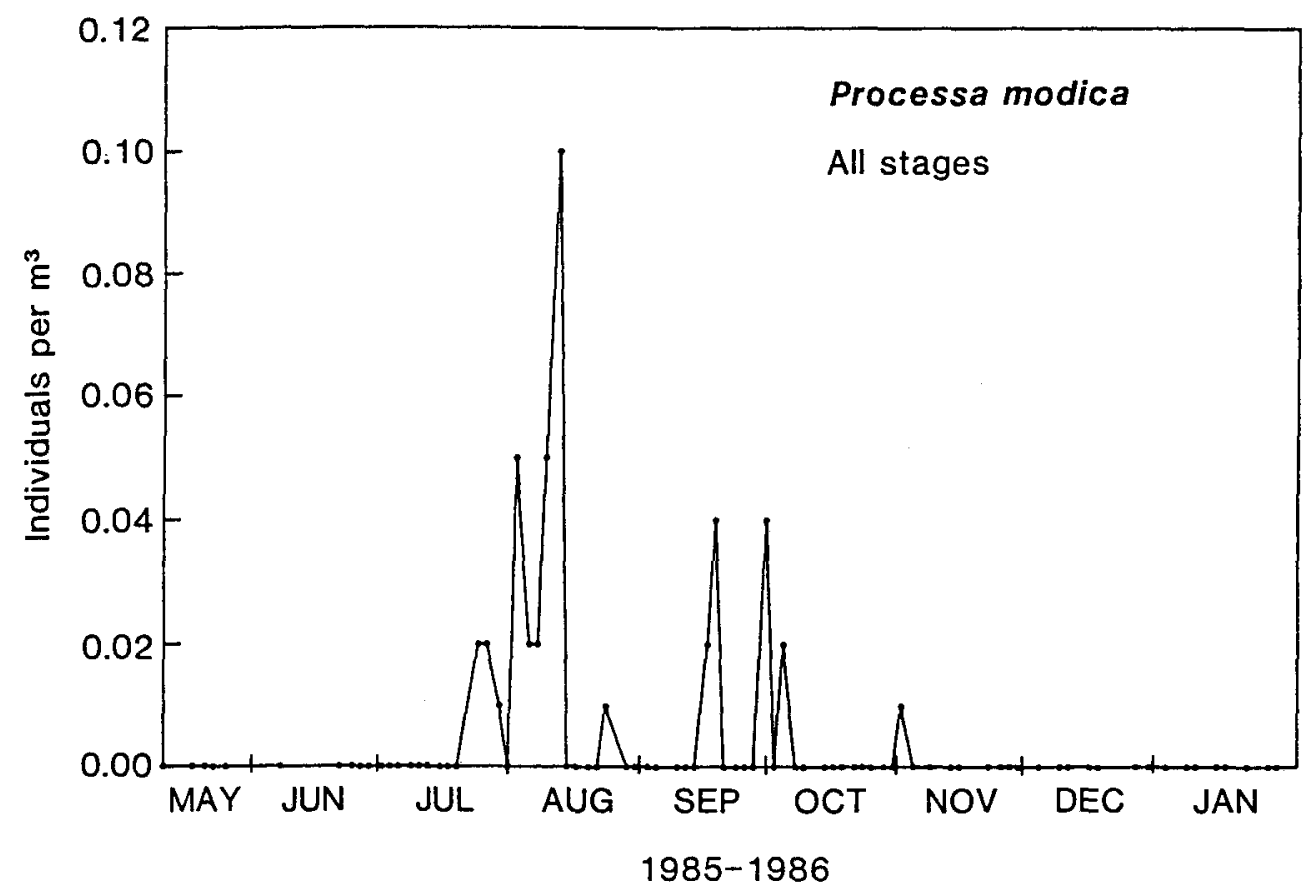

Fig. 16. Processa modica. Concentration of larvae during the sample period at Helgoland

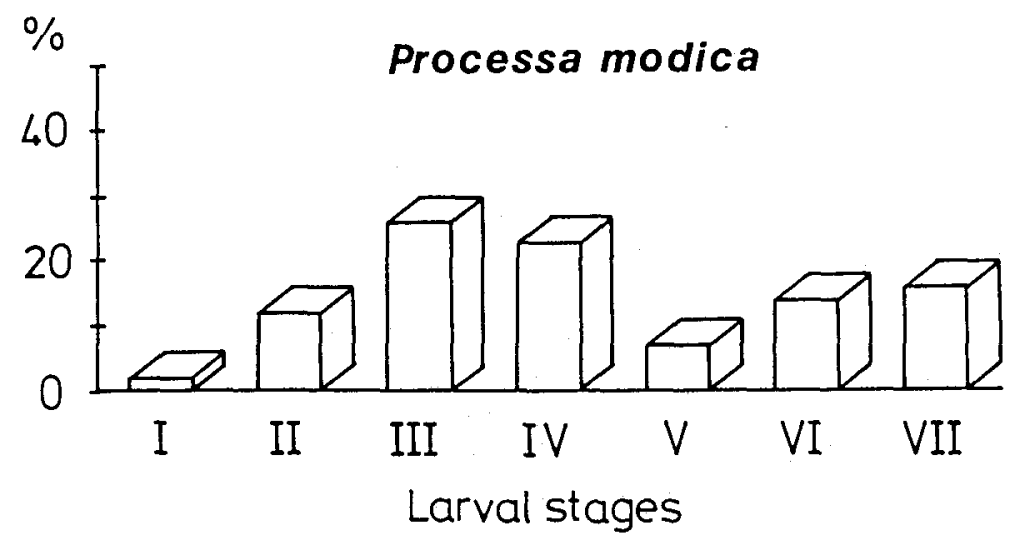

Fig. 17. Processa modica. Percentage of larval stages collected during the sample period at Helgoland $(n=36)$

Among other locations, Williamson \& Rochanaburanon (1979) reported $P$. modica larvae from the Southern North Sea, ranging from the Dogger Bank to the coast of the Netherlands and Belgium. The presence of all larval stages near Helgoland indicates that the distribution of this shrimp in the Southern North Sea extends the range given by Williamson \& Rochanaburanon (1979). P. modica larvae have been reported from the Irish Sea from July to October (Williamson \& Rochanaburanon, 1979), and Lindley (1987) 
obtained the larvae in different areas of the North Sea in July, August and November, in good agreement with the present study.

Processa nouveli holthuisi Al-Adhub \& Williamson, 1975

On two occasions (October 9 and 28), $P$. nouveli holthuisi larvae were taken from the plankton near Helgoland. The average temperature in October was $14.0^{\circ} \mathrm{C}$. Overall, two larvae in stage $\mathrm{V}$ and two larvae in stage VII were found.

Little information concerning seasonal and geographical distribution of $P$. nouveli holthuisi larvae exists. In the Irish Sea, Rochanaburanon \& Williamson (1976) collected ovigerous females from February to September. Larvae have been hatched in the laboratory in March and later months and were present in the plankton until late September. Lindley (1987) found $P$. nouveli holthuisi larvae in the North Sea, but not in the German Bight. Seasonal occurrence extended from June to September.

Larvae of $P$. nouveli holthuisi can be reared successfully from hatching to metamorphosis at $15^{\circ} \mathrm{C}$ and $20^{\circ} \mathrm{C}$ (Rochanaburanon \& Williamson, 1976). The time to metamorphosis averages about 49 days at $15^{\circ} \mathrm{C}$ (Williamson \& Rochanaburanon, 1979). In the present work, advanced larvae were obtained in October, indicating that larval development took place in August and September. These months, including July, were characterized by the highest mean temperatures during the sample period (Fig. 2). Rochanaburanon \& Williamson (1976) concluded from their laboratory experiments that many $P$. nouveli holthuisi larvae must hatch in the Irish Sea at temperatures in which their chances of survival are extremely low, although the larvae probably develop as well below optimum temperature conditions. The comparably low temperatures during seasonal occurrence of $P$. nouveli holthuisi at Helgoland may explain the low numbers of collected larvae.

\section{Hippolyte varians Leach, 1814}

Larval occurrence of $H$. varians was restricted during the study period from the end of October to early November. The specimens $(n=11)$ were collected at temperatures ranging from $9.7^{\circ} \mathrm{C}$ to $13.5^{\circ} \mathrm{C}$. The samples never contained more than 0.05 larvae per $\mathrm{m}^{3}$. Only larvae in stages III and IV were found.

Previous studies reported $H$. varians larvae from the North Sea throughout the year, and in advanced developmental stages between August and January (Baan et al., 1972). Although the results provided by Rees (1952) are only based upon $45 \mathrm{H}$. varians larvae collected during the sample period from 1947-49, they document larval occurrence from July to January with peak abundance in October. Lindley (1987) obtained larvae in the North Sea in August and November.

\section{Athanas nitescens Leach, 1814}

Larvae of $A$. nitescens were rarely collected near Helgoland $(n=6)$. They occurred between mid-August and early September within a temperature range of $14.7^{\circ} \mathrm{C}$ to $17.0^{\circ} \mathrm{C}$. Maximum concentration of 0.05 larvae per $\mathrm{m}^{3}$ (all in stage $\mathrm{V}$ ) was observed at the end of August. Larvae in stage II, IV, and VIII as well as juveniles were recorded.

In good agreement with the present study, Paula (1987) obtained maximum concentration of $A$. nitescens larvae in August and September on the Portuguese Atlantic coast. However, no recent studies on larval occurrence of $A$. nitescens in the North Sea are 
available. Lebour (1947) noted them in the inshore plankton of Plymouth between June and October, coincident with findings concerning larval occurrence of $A$. nitescens near the Danish coast (Thorson, 1946) and in the Baltic Sea (Kändler, 1961). Tambs-Lyche (1962) explained the distribution of adult A. nitescens in Scandinavian waters as a possible transportation from the English Channel along the continental coast by the general current patterns; this may also be true for their larvae. However, Schellenberg (1928) and more recently Janke (1986), reported adult $A$. nitescens from Helgoland.

Caridion steveni Lebour, 1930

On August 16, 1985 one single larva in stage IX was collected. The temperature was $16.6^{\circ} \mathrm{C}$.

Information on geographical distribution of $C$. steveni was given by $\mathrm{O}^{\prime}$ Ceidigh \& McGarth (1981). Based on one larva obtained at Helgoland by Hagmeier (unpublished), it was suggested that $C$. steveni must occur around this island (Lebour, 1930). This assumption can now be confirmed by the present larval record as well as by the observation of two $C$. steveni larvae in the last larval stage collected by the author on August 1, 1983 at Helgoland.

In the Adriatic Sea, C. steveni larvae occur from May to November, but only in low numbers (Kurian, 1965) which corresponds with the results from the Mediterranean Sea (Bourdillion-Casanova, 1960; Vives, 1966). Lebour (1947) reported the larvae from the English Channel appearing in the plankton from April to June and in October, but never in numbers. Recently, Lindley (1987) collected $C$. steveni larvae in June in the western entrance of the English Channel, and Paula (1987) found them in May at water temperatures between $14^{\circ} \mathrm{C}$ and $15^{\circ} \mathrm{C}$ at the south-western coast of Portugal.

\section{General species composition}

Planktonic stages representing 11 species of caridean shrimps were identified in the present study. The absence of any species does not necessarily imply that it does not occur in the plankton near Helgoland. It must be stressed that the results of the present paper are restricted to a one-year sampling period. Further studies in successive years may show a different species composition. However, Crangon larvae are assumed to be the most abundant shrimp species in the plankton community at Helgoland.

Crangon larvae were by far the most abundant specimens, comprising more than $90 \%$ of the total numbers of the collected larvae during the sample period (Fig. 18). Their predominance was expected due to the proximity of the sample station to Wadden Sea areas, the preferred habitat for the common shrimp, C. crangon. However, C. allmanni larvae were also remarkably abundant especially in June. In this month, approximately $53 \%$ of all Crangon larvae belonged to $C$. allmanni. Furthermore, the highest density of any species during the entire sample period (approximately 8 individuals per $\mathrm{m}^{3}$ ) was of C. allmanni larvae in mid-June. These findings can be explained by the proximity of the C. allmanni population near Helgoland.

The number of larval shrimp species near Helgoland can be compared with previous investigations conducted in the North Sea. During a sample period of 6 years near the Dutch coast, larvae of only 8 shrimp species were obtained (Baan et al., 1972). Recently, Lindley (1987) reported 14 species of caridean shrimp larvae collected by the Continuous 


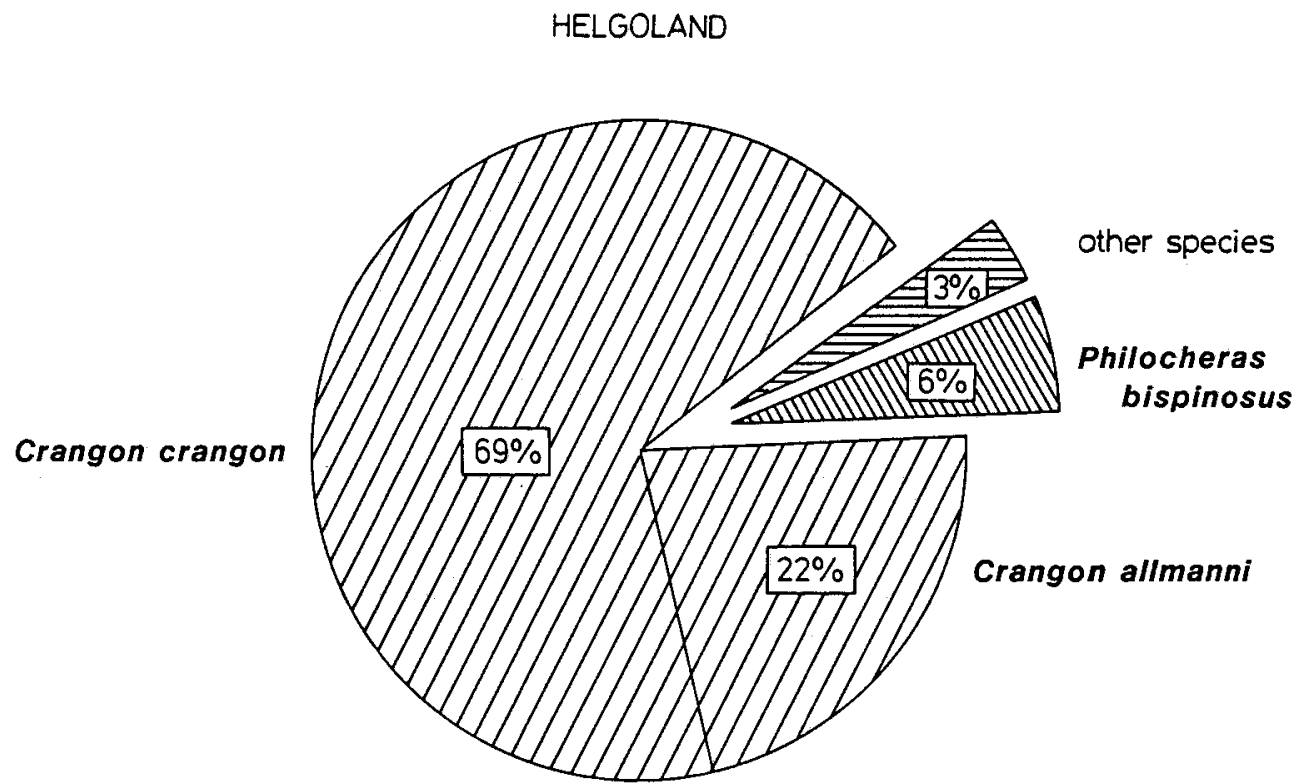

Fig. 18. Percentage of the predominant shrimp larvae obtained during the sample period (January 1985 until January 1986) at Helgoland $(n=7697)$

Plankton Recorder from 5 standard areas representing the middle and southern part of the North Sea. The higher number of species found by Lindley (1987) may be due to a longer sampling period ( 3 years compared with one year at Helgoland) and a wider geographical sampling area, including the English Channel which represents a zoogeographical connection to the Atlantic fauna. Lebour (1947) also found more species in the plankton near Plymouth during the years 1940-45. Due to the inshore sample station, she collected species typical for rivers and estuaries, while at Helgoland no strong influence of brackish water masses can be observed.

Larvae of two more species were expected to be found near Helgoland: both Pandalus montagui Leach and Pandalina brevirostris (Rathke) have been reported for Helgoland (Schellenberg, 1928; Caspers, 1939; Holthuis, 1950). The absence of $P$. montagui larvae may be due to seasonal migrations (Mistakidis, 1957; Simpson et al., 1970; Stevenson \& Pierce, 1985) and/or to annual fluctuations in larval occurrence as observed in different shrimps (Baan et al., 1972). However, in February 1986 females with eggs were collected near Helgoland ("Tiefe Rinne") and the hatching larvae were reared in the laboratory. Furthermore, on March 21, 1986 one single P. montagui larva was obtained from the plankton. These observations suggest that $P$. montagui larvae should be added to the list of species occurring near Helgoland.

More than 50 adult specimens of $P$. brevirostris were collected between October 1985 and March 1986 near Helgoland ("Tiefe Rinne"). However, the samples never contained females with eggs. Allen (1965) found some evidence of migration to and from deeper water at the beginning and at the end of the breeding season. Further studies are needed to determine whether Helgoland represents a hatching area for $P$. brevirostris. 
The comparatively high number of species of shrimp larvae at Helgoland is based on the special biotope around this island: Helgoland is surrounded by the only rocky intertidal zone in the German Bight with its typical flora and fauna (Lüning, 1970; Janke, 1986). Fucus and Laminaria species represent the preferred habitat for many different shrimps, e.g. E. pusiolus, E. occultus, H. varians and A. nitescens (Smaldon, 1979), which could explain the larval occurrence of these four species in the studied area.

\section{General relative abundance and seasonal occurrence}

A total of 7697 shrimp larvae were collected during the study period at Helgoland. Most larvae (2960) were obtained in August. However, mean concentration of larvae, based on the samples which contained specimens, was highest in June 1985 with approximately 5 larvae per $\mathrm{m}^{3}$ (Table 2). Highest relative abundance was observed on June 21 , when ca $70 \%$ of the collected specimens belonged to C. allmanni, the majority

Table 2. Mean larval concentration with standard deviation (larvae per $\mathrm{m}^{3}$ ) between May 1985 and January 1986 at Helgoland, excluding samples without shrimp larvae

\begin{tabular}{|ccccc|}
\hline & \multicolumn{4}{c}{ Larval concentration } \\
1985-86 & $\overline{\mathrm{x}}$ & $\begin{array}{c}\text { (larvae per } \mathrm{m}^{3} \text { ) } \\
\text { Minimum }\end{array}$ & Maxirnum \\
\hline May & 0.20 & 0.20 & 0.06 & 0.55 \\
Jun & 5.46 & 4.54 & 0.49 & 11.24 \\
Jul & 1.49 & 1.24 & 0.22 & 3.48 \\
Aug & 3.50 & 2.11 & 0.64 & 8.33 \\
Sep & 2.10 & 2.33 & 0.03 & 7.62 \\
Oct & 0.30 & 0.37 & 0.02 & 1.38 \\
Nov & 0.17 & 0.23 & 0.01 & 0.67 \\
Dec & 0.03 & 0.02 & 0.01 & 0.04 \\
Jan & 0.01 & 0.01 & 0.01 & 0.02 \\
\hline
\end{tabular}

to stage I. Due to the low number of samples in this month (5 compared with 13 in July and 12 in August and October, respectively), the number of the collected shrimp larvae were lower than in the following 3 months.

No comparable data for the German Bight or Southern North Sea are available. However, Rees (1955) found maximum numbers of decapod larvae in the Southern North Sea during the years 1949-51 between June and September; 1950 was characterized by decreased numbers of larvae in July, while peak abundance was obtained in June and August, which is in agreement with the results of the present study (Table 2). Furthermore, the majority of decapod crustaceans in the North Sea reaches peak larval abundance in June, August, and September; only two species had highest concentration in July (Lindley, 1987). However, Sankarankutty (1975) obtained peak abundance of decapod larvae in two west-norwegian fjords in July/August.

Temperature is probably one of the most important factors in affecting the life and survival of meroplanktonic organisms. The relationship between temperature and incubation period in decapod crustaceans has been studied by Wear (1974). Rees (1952) and Lindley (1987) discussed the influence of temperature on distribution and seasonal 
occurrence of decapod larvae. The effects of food and salinity on development of decapod larvae have been well documented (e.g. Broad, 1957; Rochanaburanon \& Williamson, 1976; Sulkin \& Norman, 1976; Criales \& Anger, 1986).

Table 3. Seasonal peak abundance of the shrimp larvae occurring near Helgoland, based on the present data

\begin{tabular}{|lccc|}
\hline Species & Jan-Jul & $\begin{array}{c}\text { Peak Abundance } \\
\text { Jul-Sept }\end{array}$ & Oct-Dec \\
\hline C. allmanni & $\mathrm{X}$ & & \\
E. pusiolus & $\mathrm{X}$ & $\mathrm{X}$ & \\
E. occultus & & $\mathrm{X}$ & \\
P. modica & $\mathrm{X}$ & \\
C. crangon & & $\mathrm{X}$ & \\
A. nitescens & & $\mathrm{X}$ \\
C. steveni & & $\mathrm{X}$ \\
P. bispinosus & & $\mathrm{X}$ \\
P. trispinosus & & $\mathrm{X}$ \\
H. varians & & & \\
P. nouveli holthuisi & & & \\
\hline
\end{tabular}

Concerning their peak of abundance during the sample period, shrimp species collected near Helgoland can be placed into three different groups (Table 3). As expected, peak abundance of most of the shrimp larvae occurred between July and September, which is in accordance with various field studies on seasonal occurrence of decapod larvae (Lebour, 1947; Rees, 1952, 1955; Lindley, 1987; Paula, 1987). Due to the relatively high water temperatures during this period; larvae have a reduced development time and a rapid growth. Experimental studies conducted with various decapod larvae showed decreased larval development time with increasing temperatures (e.g. Costlow \& Bookhout, 1969; Sandifer, 1973; Dawirs, 1979, 1985; Anger, 1983; Criales \& Anger, 1986). However, the chance for larvae to survive pelagic predation is lower than in early spring or at the end of the year (Creutzberg \& Leeuwen, 1980). Due to rapid development, the main settlement of juvenile shrimps is likely to take place during the time of the year which represents the most advantageous period for the remainder of their life span, so that the survival rate will probably be enhanced during winter.

The main hatching activities of $C$. allmanni and $E$. pusiolus occurred in spring, indicating a preference for lower temperatures. Laboratory experiments with C. allmanni larvae (Criales \& Anger, 1986) support these findings; however, corresponding data for $E$. pusiolus larvae are not available. The results of the present study showed a well separated period of larval abundance in the two Eualus species found at Helgoland. The end of the seasonal occurrence of $E$. pusiolus coincided with the beginning of the occurrence of $E$. occultus larvae. The difference may suggest different reproductive strategies and/or different temperature preferences of these two closely-related species. But again, it must be considered that the results are only based on a one-year study.

The advantage of an early hatching period may be explained by diminishing numbers of pelagic predators within this season (Creutzberg \& Leeuwen, 1980; Boddeke, 
1982) due to the low temperatures. When adequate provision of suitable food organisms is available, larvae can metamorphose in summer and can grow rapidly. This enhances the survival rate in winter and provides them a good start in the following spring.

The third group reached their peak abundance between October and December, a period characterized by decreasing temperatures near Helgoland (Fig. 2). The larval occurrence of the four species given in Table 3 indicates late hatching activities and a tolerance of low temperatures during larval development. The findings of seasonal occurrence regarding $P$. bispinosus, $P$. trispinosus and $H$. varians coincide with observations from several authors (Lebour, 1947; Rees, 1952; Lindley, 1987; Paula, 1987) who generally obtained these larvae rather late in the year. So far, laboratory studies describing the preferred temperature range for these three species of caridean shrimp larvae have not been conducted. It is assumed, that $P$. nouveli holthuisi does not fall into this group, although larvae occurred in October, but they were in advanced developmental stages.

Species in this group benefit also from the diminished number of pelagic predators. On the other hand, low temperatures will prolong the developmental duration and/or will prevent further larval development [e.g. neither $C$. crangon nor $C$. allmanni can be reared successfully from hatching to metamorphosis at $6{ }^{\circ} \mathrm{C}$ (Criales \& Anger, 1986)]. It may be that in the winter the mortality rate within the third group is higher than in the others. Furthermore, predominant settlement of juvenile shrimps falls into a period of low temperatures which represents a physiological unfavorable temperature regime.

Acknowledgements. This paper is based on a thesis submitted in partial fulfillment of the requirements for the Diploma at the University of Hamburg. I am very grateful for the advice and support from my advisor, Prof. Dr. G. Hartmann, University of Hamburg. I wish to thank the Biologische Anstalt Helgoland, especially Prof. Dr. H.-P. Bulnheim, Dr. G. Uhlig, and Dr. K. Anger, for laboratory space and working facilities. K. Treutner and P. Mangelsdorf of the Biologische Anstalt Helgoland allowed me to use their unpublished oceanographic data. Thanks are also due to Dr. K. D. Hammer (University of Hamburg) and Dr. G. Kattner (Alfred-Wegener-Institut für Polar- und Meeresforschung) for their assistance with computer work. Dr. T. Bianchi (Institute of Ecosystem Studies) as well as Prof. A. Dittel (Universidad de Costa Rica) and E. Rutherford (University of Maryland) gave valuable comments on the manuscript. Helpful suggestions were also given by anonymous referees.

\section{LITERATURE CITED}

Adema, J., Creutzberg, F. \& Noort, G. J. van, 1982. Notes on the occurrence of some poorly known Decapoda (Crustacea) in the southern North Sea. - Zool. Bijdr. 28, 9-32.

Allen, J. A., 1960. On the biology of Crangon allmanni Kinahan in Northumberland waters. - J. mar. biol. Ass. U.K. 39, 481-508.

Allen, J. A., 1965. Observations on the biology of Pandalina brevirostris (Decapoda, Crustacea). J. mar. biol. Ass. U.K. 45, 291-304.

Allen, J. A., 1966. The rhythms and population dynamics of decapod Crustacea. - Oceanogr. mar. Biol. 4, 247-265.

Anger, K., 1983. Temperature and the larval development of Hyas araneus L. (Decapoda: Majidae); extrapolation of laboratory data to field conditions. - J. exp. mar. Biol. Ecol. 69, 203-215.

Baan, S. M. van der, Holthuis, L. B. \& Schrieken, B., 1972. Decapoda and decapod larvae in the surface plankton from the southern North Sea near "Texel" lightship. - Zool. Bijdr. 13, 75-97.

Boddeke, R., 1975. Autumn migration and vertical distribution of the brown shrimp Crangon crangon L. in relation to environmental conditions. In: 9th European Marine Biology Symposium. Ed. by H. Barnes. Univ. Press, Aberdeen, 483-494. 
Boddeke, $R$, 1976. The seasonal migration of the brown shrimp Crangon crangon. - Neth. J. Sea Res. 10, 103-130.

Boddeke, R., 1982. The occurrence of winter and summer eggs in the brown shrimp (Crangon crangon) and the pattem of recruitment. - Neth. J. Sea Res. 16, 151-161.

Bourdillon-Casanova, L., 1960. Le méroplancton du Golfe de Marseille: Les larves de crustacés décapodes. - Recl. Trav. Stn mar. Endoume 30, 1-286.

Broad, A. C., 1957. The relationship between diet and larval development of Palaernonetes. - Biol. Bull. mar. biol. Lab., Woods Hole 112, 162-170.

Bull, H. O., 1939. The newly hatched larva of Spirontocaris pusiolus (Kroyer). - Rep. Dove mar. Lab. $3(6), 43-44$.

Caspers, H., 1939. Die Bodenfauna der Helgoländer Tiefen Rinne. - Helgoländer wiss. Meeresunters. $2,1-112$.

Costlow, J. D. \& Bookhout, C. G., 1969. Temperature and meroplankton, - Chesapeake Sci. 10, $252-257$

Costlow, J. D. \& Bookhout, C. G., 1970. Marine larvae - the neglected link in biological resources. Proc. Ser. Symp. Hydrobiol, Miami Beach, Fla, 8, 228-239.

Creutzberg, F. \& Leeuwen, F. van, 1980. The life cycle of Crangon allmanni Kinahan in the Southern North Sea. - C. M./ICES, L 71, 1-11.

Criales, M. M., 1985. Untersuchungen zur Larvalentwicklung von Crangon crangon L. und Crangon allmanni Kinahan (Decapoda, Natantia, Caridea). Diss., Univ, Kiel, 233 pp.

Criales, M. M. \& Anger, K., 1986. Experimental studies on the larval development of the shrimps Crangon crangon and C. allmanni. - Helgoländer Meeresunters. 40, 241-265.

Dalla-Torre, K. W., 1889. Die Fauna von Helgoland. - Zool. Jb. 2 (Suppl.), 1-99.

Dawirs, R., 1979. Effects of temperature and salinity on larval development of Pagurus bernhardus (Decapoda: Paguridae). - Mar. Ecol. Prog. Ser. 1, 323-329.

Dawirs, R., 1985. Temperature and larval development of Carcinus maenas (Decapoda) in the laboratory; predictions of larval dynamics in the sea. - Mar. Ecol. Prog. Ser. 24, 297-302.

Ehrenbaum, E., 1890. Zur Naturgeschichte von Crangon vulgaris Fabr. - Mitt. dt. SeefischVer. (Sekt. Küsten- und Hochseefisch.), Sonderbeil., 9-124.

Elss, U., 1973. Vorkommen und Häufigkeit der Garnelenlarven Crangon crangon L. vor den deutschen Küsten während der Wintermonate der Jahre 1968-70 im Vergleich zur sommerlichen Verbreitung. - Arch. FischWiss. 24, 77-86.

Gerdes, D., 1985. Zusammensetzung und Verteilung von Zooplankton sowie Chlorophyll- und Sestongehalte in verschiedenen Wassermassen der Deutschen Bucht in den Jahren 1982/83. Veröff. Inst. Meeresforsch. Bremerhaven 20, 119-139.

Goedecke, E., 1952. Das Verhalten der Oberflächentemperatur in der Deutschen Bucht während der Jahre 1872-1950 und der Zusammenhang mit dem der nordwest-europäischen Meere. - Ber. dt. wiss. Kommn Meeresforsch. 13, 1-31.

Goedecke, E., 1954. Über Ergebnisse neuerer Untersuchungen der Temperaturverhältnisse in der Deutschen Bucht. - Ber. dt. wiss. Kommn Meeresforsch. 13, 283-297.

Gurney, A. R., 1982. The larval development of Crangon crangon (Fabr. 1795) (Crustacea: Decapoda). - Bull. Br. Mus. nat. Hist. (Zool.) 42, 247-262.

Henderson, P. A. \& Holmes, R. A. H., 1987. On the population biology of the common shrimp Crangon crangon (L.) (Crustacea: Caridea) in the Severn Estuary and Bristol Channel. - J. mar. biol. Ass. U.K. 67, 825-847.

Holthuis, L. B., 1950. Decapoda. A. Natantia, Macrura Reptantia, Anomura en Stomatopoda. - Fauna Ned. 15, 1-166.

Janke, K, 1986. Die Makrofauna und ihre Verteilung im Nordost-Felswatt von Helgoland. Helgoländer Meeresunters. 40, 1-55.

Jorgensen, O. M., 1923. Plankton investigations, 1921-22. III. Marine plankton (4): Crustacea. - Rep. Dove mar. Lab. (N.S.) 12, 112-133.

Kändler, R., 1961. Über das Vorkommen von Fischbrut, Dekapodenlarven und Medusen in der Kieler Förde. - Kieler Meeresforsch. 17, 48-64.

Kingsley, J. D., 1886. The development of Crangon vulgaris. - Essex Inst. Bull. 18, 99-153.

Koslowski, G., 1985. Der Eiswinter 1984/85 im deutschen Küstengebiet zwischen Ems und Trave. Dt. hydrogr. Z. 38, 225-232. 
Kühl, H., 1972. Hydrography and biology of the Elbe estuary. - Oceanogr. mar. Biol. 10, $225-309$.

Kühl, H. \& Mann, H., 1963a. Das Vorkommen der Garnelenlarven (Crangon crangon L.) in der Elbemündung, - Arch. FischWiss. 14, 1-7.

Kühl, H. \& Mann, H., 1963b. Uber das Zooplankton der Unterelbe. - Veröff. Inst. Meeresforsch. Bremerhaven 8, 53-69.

Kühl, H. \& Mann, H., 1963c. On the distribution of shrimp larvae (Crangon crangon L.) in the estuary of the Elbe. - Veröff. Inst. Küst.- u. Binnenfisch. 27, 50-52.

Kühl, H. \& Mann, H., 1968. Über das Zooplankton der unteren Ems. - Veröff. Inst. Meeresforsch. Bremerhaven 11, 119-135.

Kühl, H. \& Mann, H., 1969. Über das Zooplankton der Unterweser und Wesermündung. - Veröff. Inst. Meeresforsch. Bremerhaven 12, 43-64.

Kühl, H. \& Mann, H., 1971. Über Hydrochemie und Plankton der Eidermündung. - Veröff. Inst. Meeresforsch. Bremerhaven 13, 163-181.

Künne, C., 1952. Untersuchungen über das Grossplankton in der Deutschen Bucht und im Nordsylter Wattenmeer. - Helgoländer wiss. Meeresunters. 4, 1-54.

Kurian, C. V., 1965. Larvae of decapod Crustacea from the Adriatic Sea. - Acta Adriat. 6, 1-108.

Labat, J.-P., 1984. Cycle de vie de Philocheras trispinosus (Hailstone) (Crangonidae: Decapoda) dans le région de Banyuls-sur-Mer (Méditerranée nord-occidentale). - Vie Milieu 34, 9-16.

Lebour, M. V., 1930. The larval stages of Caridion, with a description of a new species C. steveni. Proc. zool. Soc. London 1930, 181-194.

Lebour, M. V., 1931. The larvae of the Plymouth Caridea. I. The larvae of the Crangonidae. II. The larvae of the Hippolytidae. - Proc. zool. Soc. London 1931, 1-9.

Lebour, M. V., 1932. The larval stages of the Plymouth Caridea. IV, The Alpheidae. - Proc. zool. Soc. London $1932,463-469$.

Lebour, M. V, 1936. Notes on the Plymouth species of Spirontocaris (Crustacea). - Proc. zool. Soc. London 1936, 89-104.

Lebour, M. V., 1947. Notes on the inshore plankton of Plymouth. - J. mar. biol. Ass. U.K. 26, 239-252.

Lindley, J. A., 1987. Continuous Plankton Records: the geographical distribution and seasonal cycles of decapod crustacean larvae and pelagic post-larvae in the north-eastern Atlantic Ocean and the North Sea, 1981-3. - J. mar. biol. Ass. U.K. 67, 145-167.

Lüning, K., 1970. Tauchuntersuchungen zur Vertikalverteilung der sublitoralen Helgoländer Algenvegetation. - Helgoländer wiss. Meeresunters. 21, 271-291.

Meredith, S. S., 1952. A study of Crangon vulgaris in the Liverpool Bay area. - Proc. Trans. Liverpool biol. Soc. $58,75-109$.

Mistakidis, M. N., 1957. The biology of Pandalus montagui Leach. -Fishery Invest., London 21 (4), 1-49.

Möller, H., 1980. A summer survey of large zooplankton, particularly scyphomedusae in the North Sea and Baltic. - Meeresforsch. 28, 61-68.

O'Ceidigh, P. \& McGarth, D., 1981. Marine fauna of Co. Wexford. 3. The first record of the adult Caridion steveni Lebour (Crustacea, Decapoda) from the Irish coast. - Ir. Nat. J. 20, 208.

Paula, J., 1987. Seasonal distribution of Crustacea Decapoda larvae in S. Torpes bay, south-western Portugal. - Investigación pesq. 51 (Supl. 1), 267-275.

Pike, R. B. \& Williamson, D. I., 1961a. Larval variation in Philocheras bispinosus (Hailstone) (Decapoda, Crangonidae). - Crustaceana 2, 21-25.

Pike, R. B. \& Williamson, D. I., 1961b. The larvae of Spirontocaris and related genera (Decapoda, Hippolytidae). - Crustaceana 2, 187-207.

Plett, A., 1965. Über das Vorkommen von Garnelenlarven (Crangon crangon) vor der deutschen Küste in den Jahren 1963-64. - Arch. FischWiss. 16, 54-67.

Rees, C. B., 1952. Continuous plankton records: the decapod larvae in the North Sea, 1947-49. Hull. Bull. mar. Ecol, 3 (22), 157-184.

Rees, C. B., 1955. Continuous Plankton Records: the decapod larvae in the North Sea, 1950-51, Bull. mar. Ecol. 4 (29), 69-80.

Reichard, A. C., 1910. Hydrographische Beobachtungen bei Helgoland in den Jahren 1893-1908. Wiss. Meeresunters. (Helgoland) $10(1), 1-42$.

Rochanaburanon, T. \& Williamson, D. I., 1976. Laboratory survival of larvae of Palaemon elegans and other caridean shrimps in relation to their distribution and ecology. - Estuar. coast. mar. Sci. $4,83-91$. 
Sandifer, P. A., 1973. Distribution and abundance of decapod crustacean larvae in the York River estuary and adjacent lower Chesapeake Bay, Virginia, 1968-69. - Chesapeake Sci. 14, 235-257.

Sandifer, P. A., 1975. The role of pelagic larvae in recruitment to populations of adult decapod crustaceans in the New York River estuary and adjacent lower Chesapeake Bay, Virginia. Estuar. coast. mar. Sci. 3, 269-279.

Sankarankutty, C., 1975. Zooplankton volume and the number of decapod (Crustacea) larvae in two west-norwegian fjords. - Sarsia 58, 35-42.

Sars, G. O., 1906. Postembryonal development of Athanas nitescens Leach. - Arch. Math. Naturv. 27 (10), 1-29.

Sars, G. O., 1912. Account of the postembryonal development of Hippolyte varians Leach. - Arch. Math. Naturv. $32(7), 1-25$.

Scheltema, R. S., 1975. Relationship of larval dispersal, gene-flow and natural selection to geographic variation of benthic invertebrates in estuaries and along coastal regions. - Estuar. Res. 1 , 372-391.

Scheltema, R. S., 1986. On dispersal and planktonic larvae of benthic invertebrates: an eclectic overview and summary of problems. - Bull. mar. Sci. 39, 290-322.

Schellenberg, A., 1928. Krebstiere oder Crustacea. - Tierw. Dtl. 10, 1-146.

Simpson, A. C., Howell, B. R. \& Warren, P. J., 1970. Synopsis of biological data on the shrimp Pandalus montagui Leach, 1814. - F.A.O. Fish. Rep. 57, 1225-1249.

Smaldon, G., 1979. British shrimps and prawns. Acad. Press, London, $126 \mathrm{pp}$.

Stevenson, D. K. \& Pierce, F., 1985. Life history characteristics of Pandalus montagui and Dichelopandalus leptocarus in Penobscot Bay, Maine. - Fish. Bull. U.S. 83, 219-233.

Sulkin, S. D. \& Norman, K., 1976. A comparison of two diets in the laboratory culture of the zoeal stages of the brachyuran crabs Rhithropanopeus harrisii and Neopanope sp. - Helgoländer wiss. Meeresunters. 28, 183-190.

Tambs-Lyche, H., 1962. Athanas nitescens Leach in Norway. - Sarsia 7, 25-28.

Thorson, G., 1946. Reproduction and larval development of Danish marine bottom invertebrates. Meddr. Kommn Havunders (Plankton) 4 (1), 1-523.

Tiews, K., 1954. Die biologischen Grundlagen der Büsumer Garnelenfischerei. - Ber. dt. wiss. Kommn Meeresforsch. 13 (3), 235-269.

Tiews, K., 1970. Synopsis of biological data on the common shrimp Crangon crangon (L., 1758). F.A.O. Fish. Synopsis $91, F R m / S 91,1167-1224$.

Tiews, K., 1983. Über die Veränderungen im Auftreten voǹ Fischen und Krebsen im Beifang der deutschen Garnelenfischerei während der Jahre 1954-1981. Ein Beitrag zur Ökologie des deutschen Wattenmeeres und zum biologischen Monitoring von Ökosystemen im Meer. - Arch. FischWiss. $34(1), 1-156$.

Vives, F., 1966. Zooplancton nerítico de las aguas de Castellón. Investigación pesq. 30, 49-166.

Wear, R. G., 1974. Incubation on British decapod Crustacea, and the effects of temperature on the rate and success of embryonic development. - J. mar. biol. Ass. U.K. 54, 745-762.

Webb, G. E., 1921. The larvae of the decapod Macrura and Anomura of Plymouth. - J. mar. biol. Ass. U.K. 12, 385-426.

Weber, W., 1984. Die Krise in der Krabbenfischerei scheint überwunden. - Infn Fischw. 31 (3), 138-139.

Wedemeyer, H., 1912. Die Carididen der Nordsee. - Wiss. Meeresunters. (Kiel) 15, 107-164.

Weigel, H.-P., 1976. Temperature and salinity observations from Helgoland Reede in 1976. - Annls biol., Copenh. 33, 35.

Williamson, D. I., 1957a. Crustacea, Decapoda: larvae. I. General. - Fich. Ident. Zooplancton 67, 1-7.

Williamson, D. I., 1957b. Crustacea, Decapoda: larvae. V. Caridea, Fam. Hippolytidae. - Fich. Ident. Zooplancton 90, 1-5.

Williamson, D. I., 1960. Crustacea, Decapoda: larvae. VII. Caridea, Fam. Crangonidae, Stenopodidae. - Fich. Ident. Zooplancton 90, 1-5.

Williamson, D. I. \& Rochanaburanon, T., 1979. A new species of Processidae (Crustacea, Decapoda, Caridea) and the larvae of the north European species. - J. nat. Hist. 13, 11-33.

Williamson, H. C., 1901. On the larval stages of decapod Crustacea. - The shrimp (Crangon vulgaris Fabr.). - Rep. Fish. Bd Scotl. 19, 92-120. 